\title{
A historical and evolutionary perspective on the biological significance of circulating DNA and extracellular vesicles
}

\author{
Janine Aucamp $^{1}$ (I) $\cdot$ Abel J. Bronkhorst $^{1} \cdot$ Christoffel P. S. Badenhorst $^{2} \cdot$ Piet J. Pretorius $^{1}$
}

Received: 14 March 2016/Revised: 20 August 2016/Accepted: 15 September 2016/Published online: 20 September 2016

(C) Springer International Publishing 2016

\begin{abstract}
The discovery of quantitative and qualitative differences of the circulating DNA (cirDNA) between healthy and diseased individuals inclined researchers to investigate these molecules as potential biomarkers for non-invasive diagnosis and prognosis of various pathologies. However, except for some prenatal tests, cirDNA analyses have not been readily translated to clinical practice due to a lack of knowledge regarding its composition, function, and biological and evolutionary origins. We believe that, to fully grasp the nature of cirDNA and the extracellular vesicles (EVs) and protein complexes with which it is associated, it is necessary to probe the early and badly neglected work that contributed to the discovery and development of these concepts. Accordingly, this review consists of a schematic summary of the major events that developed and integrated the concepts of heredity, genetic information, cirDNA, EVs, and protein complexes. CirDNA enters target cells and provokes a myriad of gene regulatory effects associated with the messaging functions of various natures, disease progression, somatic genome variation, and transgenerational inheritance. This challenges the traditional views on each of the former topics. All of these discoveries can be traced directly back to the iconic works of Darwin, Lamarck, and their followers. The history of cirDNA that has been revisited here is rich in information that should be considered in clinical practice,
\end{abstract}

Janine Aucamp

aucampj@telkomsa.net

1 Centre for Human Metabolomics, Biochemistry Division, North-West University, Potchefstroom 2520, South Africa

2 Department of Biotechnology and Enzyme Catalysis, Institute of Biochemistry, Greifswald University, Felix-Hausdorff-Str. 4, 17487 Greifswald, Germany when designing new experiments, and should be very useful for generating an empirically up-to-date view of cirDNA and EVs. Furthermore, we hope that it will invite many flights of speculation and stimulate further inquiry into its biological and evolutionary origins.

Keywords Inheritance of acquired characteristics . Pangenesis - Metabolic DNA · Genometastasis . Virtosomes · Lateral gene transfer

\section{Introduction}

In 1928, Fred Griffith [1] discovered that infectious bacteria, which had been heat-killed, could transfer a pathogenic property to a live non-pathogenic strain via an interchange of culture medium. Subsequent experiments by Avery et al. [2] indicated that such an acquisition of a pathogenic property can be ascribed to the transmission of nucleic material. Apart from paving the way to the discovery that DNA is the substance of inheritance, these observations were the first evidence for the existence of nucleic acids beyond the confinement of cells [3]. Shortly thereafter, another pivotal discovery was made when Mandel and Métais [4] demonstrated the presence of extracellular nucleic acids in human blood. In the two succeeding decades nucleic acids were found to be present in the extracellular environment of organisms from all kingdoms of life [5]. Although these nucleic acids were originally termed extracellular nucleic acids, the term "circulating nucleic acids in plasma and serum" (CNAPS) was adopted when numerous studies demonstrated the presence of tumor-derived nucleic acids in plasma and serum. This term was then gradually replaced by less awkward grammatical constructions, including circulating 
nucleic acids (cirNAs), cell-free nucleic acids (cfNAs), and circulating cell-free nucleic acids (ccfNAs). Although these terms are still used interchangeably, cirNAs is now the most commonly used. When referring only to the DNA fraction, the term circulating DNA (cirDNA) is used, although the term cell-free DNA (cfDNA) is used interchangeably. However, for the purposes of this review, the term cirDNA will be used to describe DNA present in biofluids, and when discussing in vitro studies, the term cfDNA will be used. Furthermore, the terms cirDNA and cfDNA describe any DNA existing in the extracellular environment, regardless of structure (association with a variety of protein complexes and extracellular vesicles).

Thus far, many endogenous and exogenous sources of cirDNA in humans have been identified, e.g., apoptosis, necrosis, bacterial, and viral DNA [6]. Although apoptosis and necrosis are considered to be the main processes for producing cirDNA, numerous studies have demonstrated that cirDNA can also be derived from active cellular release mechanisms [7-12]. Further examination showed that actively released DNA is often associated with RNA and a lipid-protein complex, can translocate to neighboring or remote parts of the body, enter target cells, and alter their biology [12-18]. In the following years, it became clear that the active release and uptake of nucleic acids are a characteristic shared by all organisms and cell types [19].

Pertaining to humans, the presence of cirDNA in human blood and the phenomenon of the lateral transfer of cirDNA between different cells within a body are implicated in a wide range of biological phenomena. First, the occurrence of elevated levels of cell-specific cirDNA in human blood has been associated with many benign and malignant diseases and other conditions. This is exemplified by many studies, in which the cirDNA derived from patients with wide-ranging conditions, such as cancer [3], preeclampsia [20], traumatic injuries [21], fatigue [22] and old-age [23], were shown to be represented by different sequences, sizes, quantities, and genetic and epigenetic alterations, as distinct from healthy individuals. These characteristics make cirDNA prime candidate biomarkers for the diagnosis and therapy monitoring of many diseases. Another exciting discovery worth mentioning here is that, in the form of cirDNA, the entire fetal genome circulates in maternal blood [24-26], enabling the non-invasive detection of several fetal genetic aberrations.

Second, several studies have demonstrated the capacity of cirDNA to act as an intercellular messenger of sorts. For example, the lateral transference of cirDNA between different cells has been implicated in oncogenesis, metastasis, the blocking of tumor growth [27-29], and the development of resistance against radiotherapy and chemotherapy [30-32]. Since our understanding of the modus operandi of intercellular communication is traditionally limited to cell- cell adhesion conduits and secreted hormones and neurotransmitters, cirDNA may provide a new perspective on how cells communicate and share potentially useful information with each other. In addition, it offers an entirely new paradigm that could potentially improve our understanding of various pathologies (discussed in "The role of circulating DNA in disease", "The bystander effect", and "Lateral transfer of circulating DNA from healthy tissues").

Finally, cirNAs may also play an active role in the shaping of genomes and ultimately the process of evolution. There is evidence not only showing that somatic cells are liable to genetic and epigenetic modification via cirNAs, but also that this information may be transferred to the germ cells. For example, DNA has been detected in EVs released by prostate cells that have been shown to interact with sperm cells [33]. More recently, Cosetti et al. [34] discovered that RNA of human melanoma cells xenografted in mice is transported via exosomes through the bloodstream to the spermatozoa, showing that somatic information can be transferred to and received by sperm cells (discussed in "Extracellular vesicles and mobile protein complexes").

However, despite showing great promise as both an investigative aid for a wide range of biological phenomena, and a potentially powerful tool for disease screening, cirDNA research already faces many challenges. In clinical diagnostics, qualitative analyses are not yet routinely applied to screen for diseases and as concerns quantitative analyses, no normal reference value has yet been correlated with any disease, and there is no cut-off value for diagnosis. Furthermore, regarding its role in intercellular communication, we currently have a very limited understanding of the cellular circuits that mediate its messaging functions, and regarding its role in somatic genome variation, transgenerational inheritance, and evolution, it still appears to be an improbable or inexplicable event for many scientists [35-37]. Except for a lack of an analytical consensus, these difficulties can be ascribed mainly to a severe insufficiency of knowledge of its biological properties and molecular origin.

Although cirDNA research is far from a fully fledged field, our capacity to probe these questions is not so much limited by technology as by our manner of thinking. We might thus very often be looking in the wrong place for answers. We contend that reviewing the early work associated with cirDNA and EVs, which has been badly neglected, is required to fully comprehend the nature of cirDNA. Concepts regarding horizontal gene transfer (HGT) and cirDNA were contemplated by many philosophers and scientists very long before (as far back as 500 years BC) its actual discovery. However, the difficulty, in that time, to discover or even conceive of such 
mechanisms resulted, for those who believed in them, in many rhetorical enquiries that were nearly impossible to reciprocate. Consequentially, many ingenious ideas have been largely abandoned, and, to this day, still populate the garbage pail of the scientific literature. The progress that has been made in biology over the last couple of decades allowed us to perform a reconstruction of the historical path that led to the discovery and concepts of cirDNA and EVs and to provide an empirically up-to-date view (Fig. 1). This is essentially the task of this review: to rediscover parts of the forest which we have lost for the sight of the trees.

\section{Earliest speculations on heredity}

\section{Ancient Greek philosophers}

Anaxagoras (500-428 BC) believed that semen contained a miniature version of all human organs that, when planted in the uterus, grew and formed a well-developed fetus (reviewed in [38]). Hippocrates (460-370 BC) expanded this idea and proposed the Pangenetic theory of inheritance (reviewed in [39]). He hypothesized that semen contained all parts of a human body, and that it was secreted from the father's healthy and unhealthy organs to produce healthy or unhealthy parts in the child (reviewed in [40]). Aristotle (384-322 BC), however, argued against this idea [39]. He believed that semen was a secretion of blood that brought life to the coagulated menstrual blood in a woman's uterus [38, 41]. Only in the seventeenth century was this hypothesis refuted when William Harvey (1578-1657) demonstrated that the uteri of pregnant deer do not contain coagulated blood [41]. Hippocrates also believed in the inheritance of acquired characteristics, based on the observations which he made about the Macrocephali race. This was a primitive culture that associated nobility with the length of one's head, and so artificially elongated it. They would begin the process immediately after birth, first manipulating the child's head by hand, and then constraining it with bandages to force a lengthened shape. Over time, the practice was no longer required as the feature became inherited. Similar findings were reported in 1855 by Rivero and Von Tschudi [42]. Multiple collections of infant mummies and a 7-month-old fetus, still enclosed within the womb of a mummy of a pregnant woman, with cranial formations similar to the artificially manipulated heads of the adults were identified. Rivero and Tschudi further identified three different Peruvian races that share an interesting osteological anomaly, and the presence of an almost triangular-shaped interparietal bone in the crania of the infant mummies. However, one cannot rule out congenital disorders, e.g., Marfan syndrome (disorder of connective tissue), as a cause for the head morphology of these mummies.

\section{Predecessors of Charles Darwin and Jean-Baptiste Lamarck}

Due to the empiricism of the seventeenth and early eighteenth century, the physical and experimental sciences were overemphasized, which restrained the deliberation of ideas on heredity. Indeed, natural history was studied primarily by ordained ministers, which led to a general belief that the world is perfectly designed. Three prominent figures held beliefs in the opposite direction. Based on Hippocrates' ideas, Pierre Louis Maupertuis (1698-1759) espoused a theory of Pangenesis, stating that particles or elements from both the father and mother were responsible for the characteristics of their offspring (reviewed in [43]). Similar to Maupertuis, Erasmus Darwin (1731-1802), the grandfather of Charles Darwin, rejected Aristotle's theory, but additionally suggested that changes in parental bodies, due to their activities, could be passed on to their children. Furthermore, he believed that one and the same kind of living filaments were and had been the cause of all organic life. These living filaments could acquire new parts in response to irritations, sensations, volitions, and associations, and could continue to improve its own inherent activity and be propagated from generation to generation [44]. He published these evolutionary speculations in Zoonomia, but never amplified them. Although the speculations of Erasmus Darwin are strikingly similar to JeanBaptiste Lamarck's theory of the inheritance of acquired characteristics (IAC), it cannot be said with confidence that Erasmus influenced Lamarck, or vice versa [43].

\section{The inheritance of acquired characteristics}

\section{Jean-Baptiste Lamarck: Heredity of adaptation}

While devising his concept of evolution, Lamarck (1744-1829) identified two separate causes responsible for evolutionary change (reviewed in [39, 43]). The first cause involved the acquisition of greater complexity and perfection. Lamarck considered the power of acquiring progressively more complex organization to gain perfection an innate potential of animal life, a law of nature that did not, according to Lamarck, require special explanation. The second cause was the capacity of organisms to react to special conditions in the environment. According to Lamarck, the adaptations encountered in nature were due to the animals re-establishing harmony with their environment when this harmony was disturbed. This required the animal to either: (1) use certain parts more frequently 
a

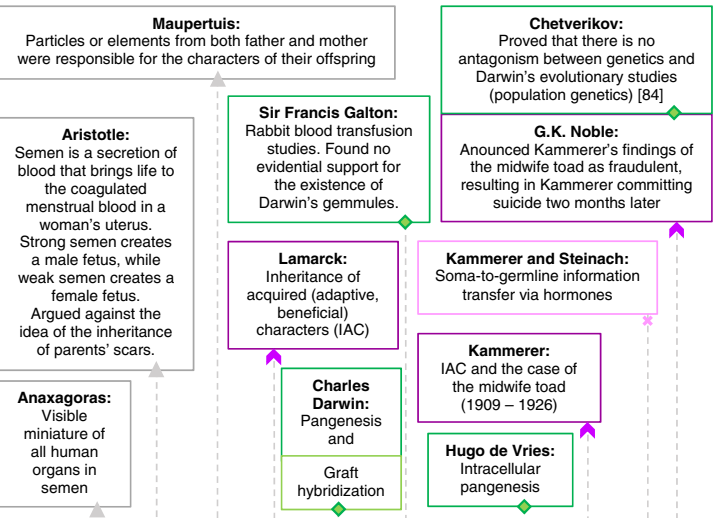

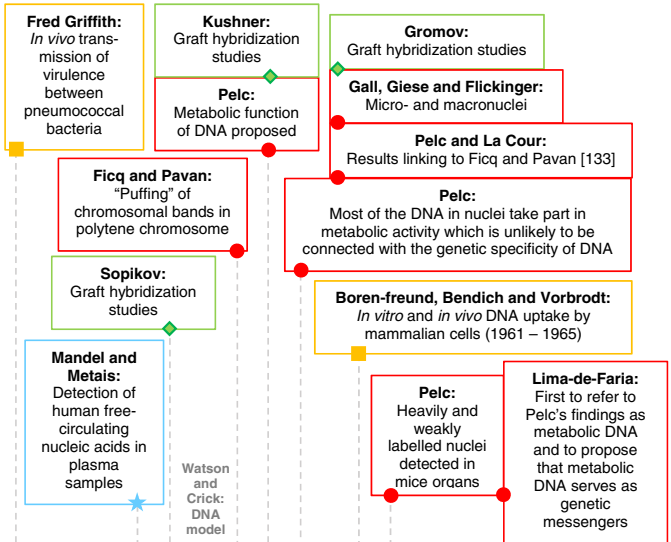

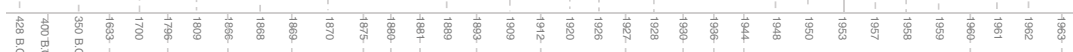
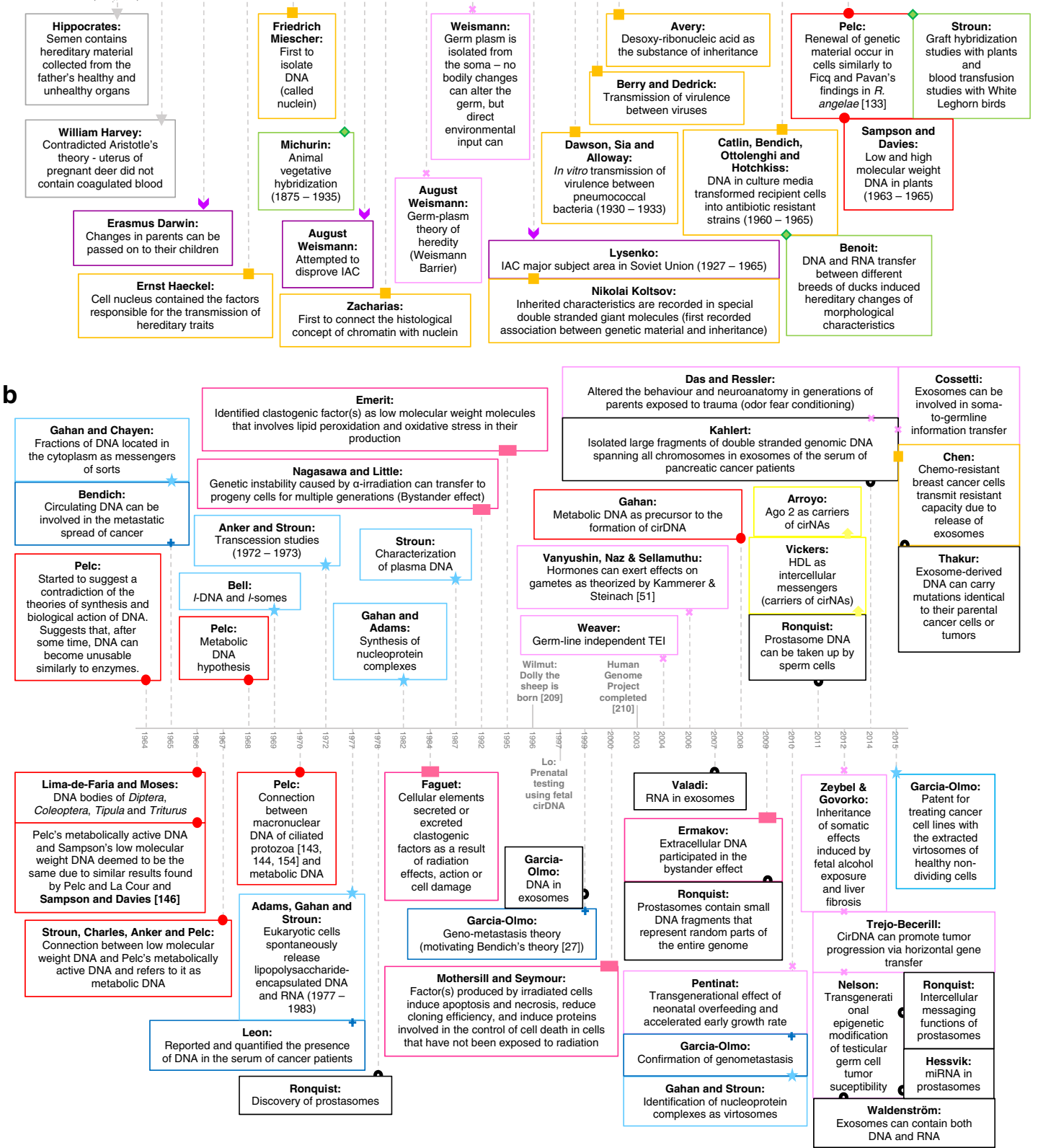
4Fig. 1 Chronological summary of the key events that led to the discovery and characterization of cirNAs and EVs from $428 \mathrm{BC}$ (a) to date (b). The research topics include inheritance theories (represented by triangles), Pangenesis and graft hybridization studies (diamonds), the inheritance of acquired characteristics (chevron), genetic material and inheritance (squares), soma-to-germline information transfer (crosses), metabolic DNA (circles), EVs (half circles), cirDNA (stars), the bystander effect (rectangles), mobile protein complexes (arrow), and cancer progression and/or metastasis (plus)

than before, considerably developing and enlarging these parts, or (2) use new parts that they have developed as a result of continuous stimulation. The idea that an organ could be strengthened by use and weakened by disuse was an ancient one. Lamarck simply provided a more rigorous physiological interpretation to this phenomenon. He considered it to be one of the cornerstones of his theory, referring to it as his "First Law" [43]. Lamarck's First Law posed the following question: How do these environmentally induced adaptations become inherited into a population? These forms of changes usually appear in a single individual or in a very small minority with respect to the population and though they tend to grow in number, there is still a risk of accidental extinction if they fail to spread among the population [45]. The accumulation of these micro-evolutionary changes, however, can result in an evolutionary change called genetic drift, a very slow process.

Lamarck's "Second Law" of evolutionary adaptation was the concept of IAC (reviewed in [43, 46]). He stated that all characteristics that individuals either acquire or lose due to environmental conditions that they were exposed to over a long period of time, were conveyed by the generation of new individuals descending therefrom, provided that the changes were present in both parents [43]. The phrase IAC was, however, quite imprecisely used by the majority of the public in that they did not emphasize the inheritance of adaptive (beneficial) traits, which Lamarck was very particular about [46]. The integration of various beliefs into Lamarck's theory of evolution made his paradigm highly persuasive, which continued to make some of his ideas widely accepted for almost a hundred years after Charles Darwin's publication of The Origin of Species in 1859 [43].

\section{The germ-plasm theory of heredity vs soma-to- germline transfer}

\section{August Weismann: the argument against IAC through introducing the Weismann barrier}

In the 1880s, August Weismann set out to disprove IAC. He hypothesized that cutting off the tails of experimental rats would not result in tailless pups or the shortening of the tail in successive generations. Indeed, long before Weismann, it was known that senseless mutilation had no effect on progeny as seen in cases of human circumcision, for instance [47]. Although Weismann's findings were irrelevant to Lamarck's original concept, it had grave ramifications on the public perception of IAC. Through the publication of multiple essays between 1883 and 1893, Weismann continued to discredit IAC and began introducing the germ-plasm theory of heredity.

Weismann's germ-plasm theory hypothesized that the nuclei of egg and sperm cells contained putative heredity particles which were transmitted from parent to child. However, contrary to IAC and Charles Darwin's Pangenesis theory (discussed in "The hypothesis of Pangenesis"), Weismann argued that these particles were immune to the lasting effects of environmental change, because he believed that germ cells were insulated from influences outside of the nucleus which allowed the preservation of parental types from significant environmental changes during transmission [48]. This theory of the immunity of germ-plasm against change was referred to as the Weismann barrier [49].

By the 1890s, the concept of "use inheritance" began to wane and Weismann's germ-plasm theory became increasingly popular, but IAC still remained favoured by many. Weismann then started suggesting that direct environmental effects on the germ-plasm were possible, but that functional changes of organs could not cause a corresponding change in the germ-plasm due to the germ being physically sequestered from not only somatic cytoplasm and idioplasm (nuclear contents), but also the germcell's cytoplasm $[47,50]$. Furthermore, he believed that the idioplasm of the germ-cell was a substance of extreme stability, as it could absorb nourishment and grow enormously without changing its complex molecular structure. To support this, he referred to the persistence of unchanged species throughout thousands of years, particularly four thousand-year-old mummies of sacred Egyptian animals that remained identical to the animals existing then. Weismann believed that external effects could only affect germ-plasm growth rate and changes in entire species and that the only factor that could allow germ-plasm variation in individuals were changes that occur during sexual reproduction when germ-plasm is rearranged to produce offspring [47].

\section{Demonstrating somatic induction in defence of IAC}

Weismann's germ-plasm theory challenged the validity of IAC by implying that if the germ-plasm and soma were affected by environmental factors only, the changes in the germ-plasm would be transmitted to offspring and the somatic effects would have no effect on the germ-plasm 
(direct or parallel induction) [50]. As mentioned in "August Weismann: the argument against IAC through introducing the Weismann barrier", Weismann believed that these environmental effects would, in any case, only influence germ-plasm growth rate or induce changes in an entire species, effectively refuting the idea that adaptive traits could be inherited by an individual. To prove that adaptive traits could be transferred from parent to offspring, one would have to demonstrate somatic induction, where the changes of only the soma would influence the germ cells to be transferred to offspring. Figure 2 briefly summarizes the progression of Hans Przibram, Paul Kammerer, and Eugen Steinach's research in support of IAC and the most prominent modern somatic induction studies that turned Weismann's theory on its head. Shortly after Steinach's discovery of hormones, the possibility of hormones-mediating somatic effects on the germline was questioned. Kammerer strongly believed that this was the case, developing a theory of somatic induction which he and Steinach tested in 1920 by exposing male rats to high temperatures, which resulted in morphological and physiological changes in their offspring and grandoffspring. It was theorized that the heat produced a change in hormone production in the interstitial cells and that the close proximity of the interstitial cells to the germ cells in the gonads facilitated hormonal interactions between them. The germline was, therefore, affected by the changes in hormone production and resulted in the inheritance of these changes by the offspring (reviewed in [51]).

Today, the concept of soma-to-germline information transfer through germline-independent transgenerational epigenetic inheritance is slowly growing. Vanyushin [52] has shown that methylation patterns in the rat genome are controlled by hydrocortisone dynamics, and a review by Naz and Sellamuthu [53] suggested that there are hormone receptors in mature sperm. Both of these studies strongly support Kammerer and Steinach's findings that hormones could exert their effects on gametes. Weaver et al. [54] showed that parenting behaviours and stress responses result in epigenetic alterations which can be transferred from the mother to her offspring. Dias and Ressler [55] showed altered behaviour and neuro-anatomy in the offspring of parents exposed to trauma in the form of odor fear conditioning. Mice were exposed to aromatic acetophenone to activate a known odorant receptor, Olfr 151, and subsequently, conceived F1 and F2 generations were then

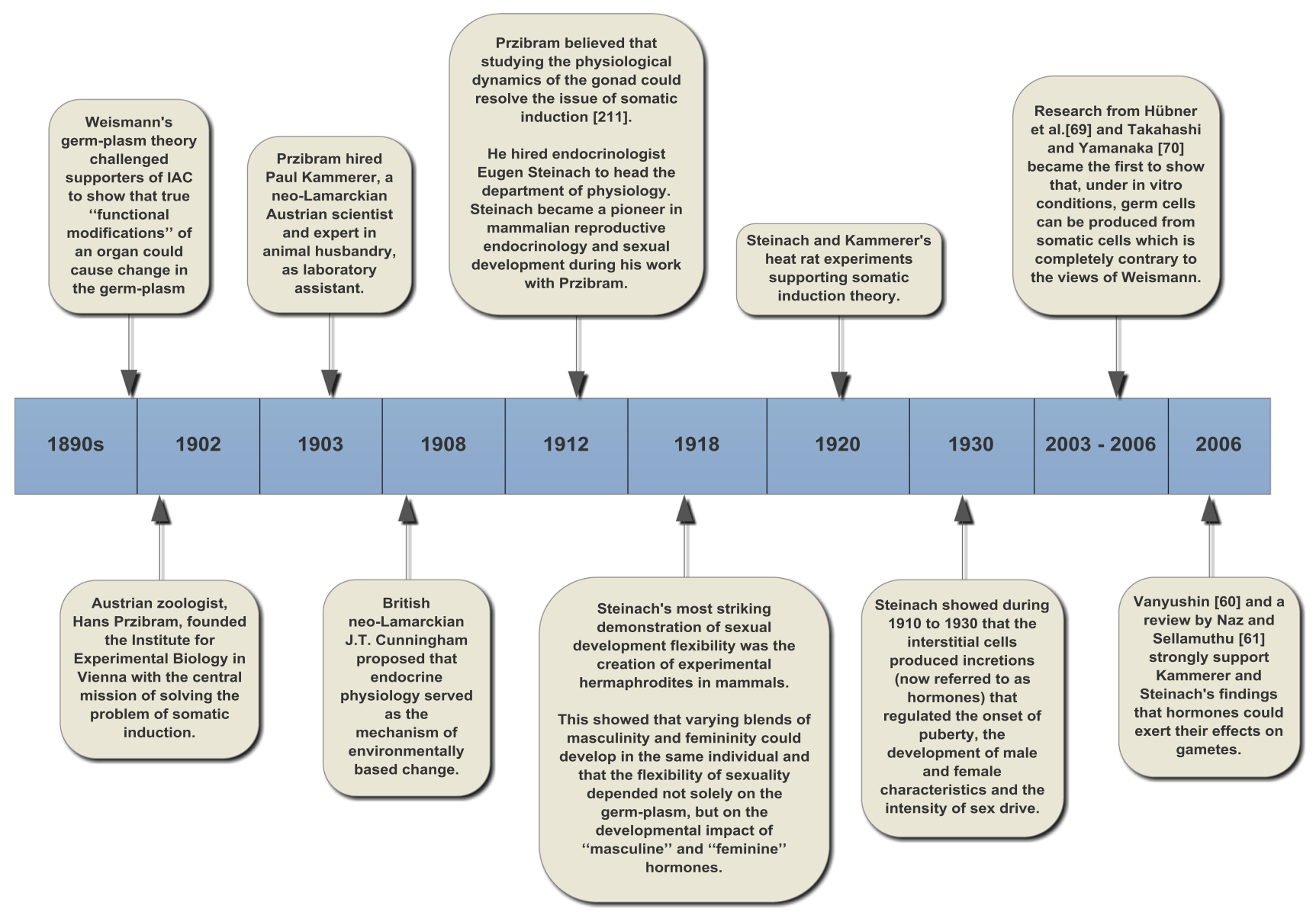

Fig. 2 Przibram and Steinach's somatic induction research [50] 
screened for behavioural sensitivity to the acetophenone odor. The resulting behavioral sensitivity was found to be complemented by enhanced neuroanatomical representation of the Olfr151 pathway and CpG hypomethylation was detected in the Olfr151 gene of the F0 males and F1 generation. In vitro fertilization, F2 inheritance and crossfostering showed that these transgenerational effects are inherited via paternal gametes. To ensure that the effects observed in the offspring were not due to direct exposure of the fetuses to the treatments, the parents were not yet pregnant when treated and cross-fostering was also applied. Nelson et al. [56] also discovered that genetically engineered Apobec1 deficiency could modify testicular germcell tumor susceptibility and embryonic viability in a transgenerational epigenetic manner. Other examples (reviewed in [57]) are the transgenetic inheritance of somatic effects induced by fetal alchohol exposure [58], neonatal overfeeding [59], and the induction of liver fibrosis [60].

In 2003, Hübner et al. [61] developed primordial germ cells or gametes from pluripotent stem cells of mice and humans. Three years later, Takahashi and Yamanaka [62] became the first to demonstrate that pluripotent stem cells can be derived from unipotent somatic mammalian cells. Researchers have, therefore, shown that, under in vitro conditions, germ cells can be produced from somatic cells which is completely contrary to the views of Weismann (that germ cells can produce both somatic and germ cells, whereas somatic cells produce only somatic cells [48]). The low probability of the fertilization of a transformed or untransformed germ cell and high turnover rate of sperm cells may limit the chances of a cirDNA-transformed sperm cell to fertilize an untransformed or transformed oocyte [63]. The successful transfer of genetic and epigenetic changes to following generations may, however, be dependent on the length and severity of exposure to the causing factor.

\section{The case of the midwife toad}

IAC became a major subject area in the 1930s to 1950 s. Sigmund Freud was interested in IAC and refused to abandon this theory, even though it had become politically charged and regarded by the Nazis as Bolshevik and Jewish (discussed in [64]). This political prejudice is said to have started with Kammerer's experiment on the midwife toad (Alytes obstetricans), terrestrial amphibians that copulate, fertilize their eggs, and carry them on land during embryonic development [65]. Kammerer conditioned midwife toads to develop characteristics similar to closely related aquatic toad species. The few resulting generations showed a greater preference to copulate in water even under the normal environmental conditions and no longer carried their eggs (reviewed in $[65,66]$ ). By generation F3, the male toads started to develop nuptial pads: rough, pigmented epidermal thickenings that male aquatic toads use to grasp the slippery females during copulation in water. However, William Bateson, a neo-Darwinist and Cambridge scientist, and G.K. Noble of the American Museum of Natural History announced that the toad was injected with India ink to create and represent nuptial pads (reviewed in [67]) and the controversial debate that followed pushed Kammerer to suicide (discussed in [65, 68, 69]). Many scientists believed that Kammerer's experiments were genuine, but his experiments were subsequently never repeated successfully. Arthur Koestler, a writer of scientific, political, and ethical issues, justified the reinvestigation of the Lamarckian experiments of Kammerer in 1971 [65, 67, 68], by identifying a natural occurrence of midwife toads with nuptial pads collected in the wild [65]. Harry Gershenowitz attempted the experiment in the 1980 s using a similar method with Bombina orientalis, but could not continue due to financial constraints [67]. In 2009, Alexander O. Vargas stated that there was no proof that the nuptial pads of the experimental midwife toad were never present [65]. He believed that Kammerer stumbled upon non-Mendelian inheritance at a time when Mendelian genetics was becoming well accepted. Kammerer's experimental results were beyond the knowledge of biology of that time and were, therefore, deemed fraudulent [69]. Kammerer's midwife toad could, thus very well, be the earliest experimental evidence of epigenetic inheritance and, perhaps, even natural somatic induction. We are, therefore, in agreement with Koestler, Gershenowitz, and Vargas that these experiments should be reinvestigated.

\section{The hypothesis of Pangenesis}

\section{Charles Darwin: variation and natural selection}

Charles Darwin believed that two operative factors govern the organic world, the variation in the reproduction and inheritance of all living organisms, and natural selection. He devoted himself to describing the second factor and his name is principally associated with it. Variation, on the other hand, received considerably less attention. To Darwin, variation was a mysterious thing for natural selection to work on, and its spontaneous and uncontrolled character puzzled him (see [70] for a beautiful discussion). Nevertheless, inspired by his grandfather, Hippocrates, Maupertuis, and Lamarck, Darwin made an attempt to understand variation and formulated the theory of Pangenesis, which he presented in the chapter "Provisional hypothesis of Pangenesis" of his book "The variation of animals and plants under domestication", which was published in 1868 [71]. 
The fundamental building blocks of the Pangenesis theory were microscopic particles that Darwin called gemmules. These particles were constantly shed by all living cells at every developmental stage. They were selfreplicating, could vary in response to the environment, and were capable of dormancy. They could then be released into the circulatory system, in which they were conveyed throughout the body, and could eventually reach the reproductive cells. Consequentially, information could be transferred to the next generation (reviewed in [19, 39, 72]). Darwin believed that gemmules could aggregate with one another or fuse into nascent cells to form new cells and connected the purpose of gemmules to not only heredity, but to the healing of wounds and regrowth of limbs (as seen in lizards). Darwin also hinted that gemmules show specificity regarding which cells they enter. He compared the affinity of gemmules for certain cells to the affinity of tissues for special organic substances, e.g., poisons only affecting certain organs or cancers and diseases affecting certain tissues or glands [71].

Darwin admitted that the sheer abundance of selfreplicating gemmules from throughout the body at every developmental stage seemed inconceivable, but compared the vast numbers of gemmules with the numerous amounts of seeds and eggs that certain plant and animal species can produce and with the amount of contagions spread by disease to show that it was not impossible. He also believed that this vast abundance of gemmules could result in certain developmental oddities, e.g., the abnormal multiplication or transposition of organs and limbs (goldfish with supernumerary limbs or the development of a double tail in lizards whose tails were severed) [71]. In cases where mutilation or amputation did not result in the regrowth of the organ, Darwin believed that the remaining damaged and diseased tissue somehow resulted in the destruction of the gemmules released by that organ before it was removed, which prevents the body from rebuilding the organ.

Although Darwin's idea of free information-carrying particles in the circulation was a "gratuitous assumption" [71], Pangenesis served as a very efficient solution to both the 1865 Mendelian theory of inheritance and a central unsolved problem in Darwin's theory of natural selection, the so-called "blending hypothesis". The latter states that the repeated 'blending' of parental traits to form new generations would eventually remove all the diversity in a population, due to a lack of new sources of variations, and could eventually bring evolution to a grinding halt (reviewed in [39]). Pangenesis provided a ready source of heritable variation, as environmentally induced changes in the cells of organisms would be transmitted to offspring via modified gemmules, providing a wide range of diversity through the inheritance of acquired traits. However, despite showing great insight, Pangenesis was never adopted by his successors [70]. In fact, they actually held strong beliefs in quite the opposite direction. On top of that, Darwin's overemphasis of natural selection did unfortunately, in all innocence, directly, and quite powerfully reinforce the mechanistic conception of the universe. In other words, the true cause of organic change and progress was, by most, ascribed to natural selection. The difficult part of the theory, which had even Darwin perplexed, the internal factor of variation, was ignored. Be that as it may, Darwin went on and devised the concept of graft hybridization, a technique in which heritable changes could be transferred over graft junctions, to test his hypothesis.

For Darwin graft, hybridization referred to the production of individuals (graft hybrids) from the united cellular tissues of two different plants [73]. He collected large amounts of information about multiple graft hybrids, including that of the Bizzaria orange, jessamine, oleander, ash, hazel, grape, hyacinths, rose, and potatoes. The most famous example of graft hybridization is that of Cytisus adami, which bore its own hybrid flowers (dingy-red color) and that of its parent plants (large, bright yellow, and small, purple flowers) due to a graft of a $C$. purpureus (purple laburnum) bud into a C. laburnum (common laburnum) stock [71] (discussed in [73]). Darwin believed that graft hybridization proved that the elements required to produce a new being were not formed by sexual organs, but were present in cellular tissues where they could unite without the aid of sexual organs to form a new bud with characteristics of both the parental sources. Although he was successful and many other well-known researchers have created and demonstrated the existence of graft hybrids (reviewed in [73]), the acceptance of it as a reality was/is challenged by the perception that the phenomenon involves "simple" chimeras (discussed in [74]).

\section{Francis Galton: argument against Pangenesis}

Darwin's half first cousin, Sir Francis Galton, believed that mental and physical traits were inherited and that a superior race of men can be created, similar to the production of a superior breed of cattle or horse (reviewed in [39]). To prove this, Galton used Belgian mathematician Adolphe Quetelet's theory of a normal curve, where measurement variables would be distributed in the form of a bell curve. The frequency of the most common variables was proportional to the area under the apex of the bell and the frequency of the outlying variables was found near the tails. Galton believed that the size of the brain, the amount of grey matter or brain fibers, and, therefore, mental capacity of a population could be plotted with this method. The Pangenesis theory provided him with further justification that intelligence, or any other mental of physical 
trait, would follow normal distribution. If a trait, in this case, intelligence was determined by two forms of a particular gemmule which exists in equal numbers in each of the parents, the result would be a bell-shaped distribution of intelligence among the offspring [39]. Pangenesis could, therefore, be used to predict the distribution of intelligence from one generation to the next. In the early 1870 s, Galton set out to demonstrate the existence of gemmules by conducting blood transfusion experiments on rabbits [75]. The study was based on the theory that gemmules had to be present in the blood to be transported from one part of the body to distant reproductive cells, making it possible to transfer these gemmules from one animal to another via blood transfusion. Focussing on morphological changes alone, he attempted to "mongrelize" silver-grey rabbits with the blood of yellow, common grey, or black and white rabbits using three different blood transfusion techniques: (1) moderate transfusion of partially defibrinated blood; (2) large transfusions of wholly defibrinated blood; and (3) the establishment of a cross-circulation system between the carotid arteries of a silver-grey and common rabbit. None of these techniques produced any morphological changes which would suggest that gemmules existed [75]. For decades then, the concept of Pangenesis was excluded from the expanding knowledge of genetics.

Karl Pearson (an influential English mathematician, biometrician, protégé and biographer of Galton), however, discredited Galton's findings in 1900 by stating that Pangenesis was no more disproved by stating that gemmules have not been found in the blood than the atomic theory is disproved by the fact that atoms have not been found in the air [76]. Furthermore, Galton's unsuccessful experiments were later questioned due to the repeated successes of modified inheritance via graft hybridization. The most prominent graft hybridization research was performed by Russian geneticist, horticulturist, and a strong supporter of Darwin's views, Ivan Vladimirovich Michurin (1855-1935). His work resulted in the creation of more than 300 new fruit plant species (reviewed in [77]) and played a major role in (1) the works of Lysenko ("Trofim Denisovich Lysenko"), (2) the investigation of the effects of blood transfusions on hereditary traits by animal breeders (known as animal vegetative hybridization), in particular studies by P.M. Sopikov who transferred multiple physical traits between various bird species ("The connection between IAC and Pangenesis"), (3) the development of the circulating DNA theory by Stroun, Anker, Gahan, and Chayen using graft hybridization in plants ("The concept of circulating DNA"), and (4) more recent immunological tolerance and HGT studies. With regard to Galton's unsuccessful blood transfusion experiments, it was proposed that transfusion incompatibilities due to blood group differences, species differences, the transfusion method, frequency, and duration, and blood volume could be factors that affected the experiment (reviewed in [72]). Moreover, heritable changes may be easier to detect in poultry than in rabbits, and also, bird erythrocytes are nucleated and contain DNA, whereas mammalian erythrocytes do not, meaning that to observe heritable changes in mammals may require larger volumes of blood transfusion and more generations of progenies.

\section{Trofim Denisovich Lysenko}

The Soviet Union was under the leadership of Josef Stalin who welcomed the actions of the agronomist Trofim Lysenko who was a follower of Michurin's graft hybridization experiments and interested by the work of Kammerer. This made matters worse for Pangenesis and IAC, in the sense that on becoming President of the Lenin Academy of Agricultural sciences of the U.S.S.R. in 1948, Morgan-Medelian genetics were considered redundant and replaced by the "progressive, materialist, Michurin trend". Lysenko became notorious for forcing Soviet scientists to accept Michurin's teachings or be banned from doing research—or killed. Thus, as a keen supporter of IAC, he led large-scale experiments on graft hybridization and the conversion of winter and spring wheat from the 1930s to the early 1960s (reviewed in [77]). Repetition of these experiments by Western geneticists produced negative results, and Lysenko was declared a forger and a criminal (discussed in detail in [78]). Later studies, however, showed evidence that supported Lysenko's findings, showing that Lysenko was, perhaps, falsely accused (discussed in detail in [73, 79]), similar to Kammerer. On the other hand, Lysenko and his assistants, many of whom were not actual scientists, also transcribed Lamarck's ideas into bizarre claims, such as the "extraordinary adaptation" of cuckoos who constantly materialized de novo from eggs was (reviewed in [46, 80, 81]). The saga of Lysenko rendered Pangenesis and Lamarckian inheritance, an unacceptable and repulsive idea to the majority of biologists for a very long time [82].

\section{De Vries: intracellular Pangenesis}

In 1889, the Dutch botanist Hugo de Vries introduced intracellular Pangenesis, a modified version of Darwin's Pangenesis. He described discrete hereditary particles (called pangenes) coding for individual cells or smaller entities inside cells that corresponded to enzymes and the most basic components of the cell (reviewed in [39]). De Vries proposed that the nuclei of all cells contained an identical collection of pangenes that served as a repository of the totality of the hereditary information and that the distinctive nature of different cell types was determined by 
the types and numbers of the pangenes transported from the nucleus to the cytoplasm. This theory has formed the crux of the modern understanding of the process of cell differentiation.

\section{DNA, heredity, and the advent of extracellular DNA}

The mid-nineteenth century marked the beginning of cytogenetics and the connections between genetic material and heredity. The events that led to the discovery of DNA, its connection to chromosomes, and to heredity are summarized in Fig. 3. In studying the nuclein of spermatozoa, Friedrich Miescher came very close to understanding the mechanisms controlling the development of an embryo and how characteristics and traits were passed on from one generation to another (reviewed in [83]). He stated that if one had to consider that a single substance is the specific cause of fertilization and heredity, then nuclein should be the first to be considered. However, Miescher did not believe that only a single substance could result in the diversity of different animal species. Although he believed that different types of nuclein could exist, he did not think that these differences would be enough to even warrant the slight differences between the individuals of the same species, because he could not imagine the combinatorial diversity possible with biological polymers. In fact, the majority of scientists believed that the more complex proteins served as the carriers of genetic information and not nuclein. It was assumed that nuclein was too small to store the vast amount of genetic information (discussed in [83]). In 1927, Nikolai Koltsov proposed that each chromatid of a chromosome consisted of one giant hereditary molecule, in which inherited characteristics were recorded (reviewed in [84]). This special giant double-stranded molecule consisted of two mirror strands that would replicate in a semi-conservative fashion using each strand as a template and each segment within this molecule would represent a gene. Koltsov's theory was confirmed 25 years later when James Watson and Francis Crick introduced their theoretical model of a double-stranded DNA helix in

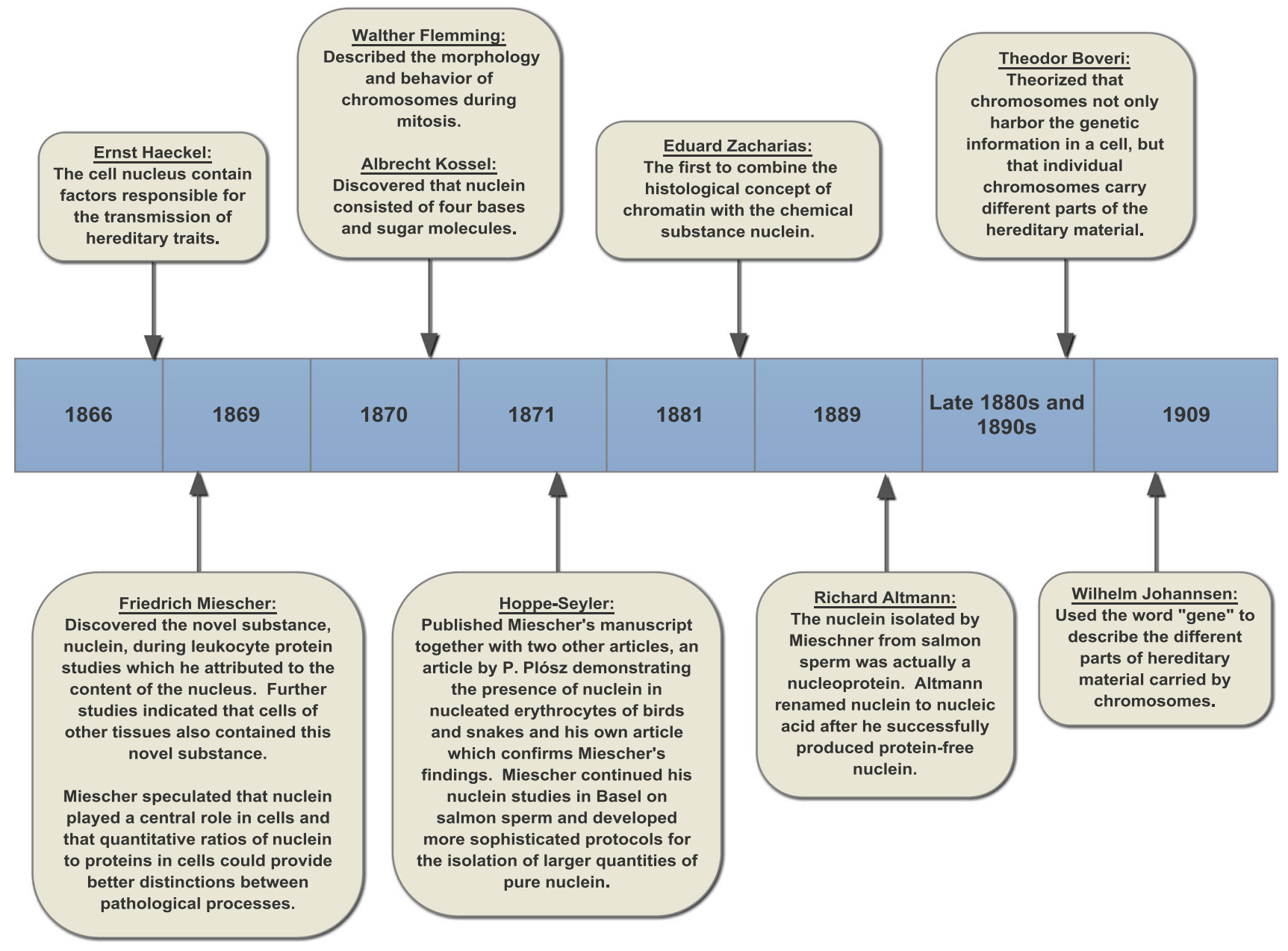

Fig. 3 Chronological summary of the events that led to the discovery and elucidation of nuclein as hereditary material in genes [83, 212, 213] 
1953 [83, 84]. Koltsov's giant hereditary molecule was the first hint that it was possible for nucleic acids to serve as genetic information carriers.

In 1928, Fred Griffith [1] described the transmission of a virulent property from pneumococcal bacteria killed by heat to a living non-virulent attenuated strain by adding large doses of the killed cells' culture to the living cells. His findings were later confirmed by several studies [85-88] and were also found to occur in viruses [89]. Avery et al. [2] demonstrated the transfer of genetic material between different pneumococcal strains by managing to isolate a biologically active fraction in a highly purified form which, in exceedingly small concentrations, could transform cultured non-virulent pneumococcal cells into virulent cells. This active fraction was determined to contain a highly polymerized and viscous form of desoxyribonucleic acid [2], proving that DNA is the substance of inheritance (the transforming principle originally described by Griffith in 1928) (reviewed in [3]). It is also the first observation of the existence of DNA beyond the confinement of cells. Later studies indicated the existence of similar DNA fractions in both plant and animal kingdoms [3] and Mandel and Métais [4] were the first to report the detection of freely cirNAs in human plasma samples. In the 1960s, Neisseria and strains of Diplococcus pneumoniae (Streptococcus pneumoniae) were found to release biologically active DNA into culture media which resulted in the transformation of recipient cells [27, 90-92], similar to the virulence transmission studies of Griffith [1]. Transformation was obtained by treating a mixture of two pneumococci strains, one of which was penicillin-resistant and streptomycin-sensitive, and the other penicillin-sensitive and streptomycin-resistant, with penicillin. The treatment resulted in the lysis of the penicillin-sensitive strain, whose DNA transformed the penicillin-resistant strain to streptomycin-resistant $[90,91]$. Similar to bacteria, mammalian cells can also take up DNA in vitro and in vivo $[6,27,93,94]$.

\section{The connection between IAC and Pangenesis}

In 1950, the Russian P.M. Sopikov became greatly inspired by Michurin's hybridization experiments. He found that the periodical transfusion of Black Australorp rooster blood to White Leghorn hens, which later mated with White Leghorn roosters, delivered offspring with noticeable modified inheritance. In exchanged donor and recipient roles, similar results were obtained. In comparison with purebred controls, changes in body mass, neck and body size, leg length, and leg pigmentation were noted. These characteristics became more pronounced in each successive generation of continually treated birds [95]. With Chuvash geese and
Bronze turkey donors and White Leghorn recipients, similar changes were observed [96]. In response to Sopikov's unexpected results, a deluge of similar investigations by different researchers followed, which included donor/recipient pairs, such as the New Hampshire chicken/White Leghorn chicken [97] and the Bronze turkey and White Leghorn chicken [98]. Most obtained positive results. Further studies outside the Soviet Union also showed similar results, including the study by Stroun et al. [99], reporting that White Leghorn birds repeatedly injected with the blood from grey guinea fowl produced progeny with grey or black-flecked feathers in second and later generations [72]. All of these experiments have provided evidential support for the existence of Darwin's gemmules. However, what really actualized the credibility of Pangenesis is the association of gemmules with the discovery of extracellular DNA in human blood [4]. For the first time, then, DNA extracted from the Khaki Campbell was exclusively used to induce heritable changes in the Pekin duck. Supplementing these results, DNA and RNA transfer between different breeds of ducks induced hereditary changes of morphological characteristics [100].

\section{The concept of circulating DNA}

Owing to the fact that Western geneticists considered graft hybridization to be a dubious technique, no one outside Russia had for a long time attempted to repeat the experiments [101]. The first to do so successfully was Maurice Stroun and colleagues [102, 103]. They found that after three generations of grafting between two varieties of eggplant, hereditary modifications were obtained in the pupil plant. However, unlike the Russians who ascribed the hereditary modifications to acquired characters, because of a change of medium, Stroun suggested that it was due to DNA circulating between the mentor and pupil plants. It was also suggested that these DNA molecules could be transported to, and integrated with the genome of the reproductive cells of the pupil plant [102].

In concurrence with Stroun, Gahan and Chayen then suggested that a fraction of the DNA located in the cytoplasm had the ability to act as a messenger of sorts [104]. Stroun and Anker then went on and partly validated the hypothesis of cirDNA when they demonstrated that DNA could travel from the bottom of a tomato stem to the upper part of the plant, after dipping the stem in purified DNA [105]. Shortly afterwards, Eugene Bell discovered informational DNA (I-DNA), a non-mitochondrial cytoplasmic DNA found in the cytoplasm of a variety of embryonic cells that are packaged in particles called I-somes, which can be associated with rapidly labelled RNA and polyribosomes [106]. Bell theorized that I-DNA, rather than 
mRNA, passes into the cytoplasm where it becomes associated with protein to form I-somes. This DNA then served as the templates for RNA synthesis, while transcription occurs after the DNA leaves the interior of the nucleus or while the DNA is associated with the outer nuclear membrane. Inhibitors of DNA synthesis do not affect I-DNA and nuclear DNA synthesis equally, indicating that I-DNA is not an artefact of tissue fractionation and DNA isolation [106, 107]. Bell's I-DNA and I-somes were hypothesized to represent copies of nuclear genes and to serve as information intermediates between the nucleus and the cytoplasm in eukaryotic cells, making them strikingly similar to De Vries' pangenes [39].

\section{The concept of transcession}

Similar to the viral and bacterial transformation studies of Griffith [1], Catlin [90, 91] and Ottolenghi and Hotchkiss [92], Anker and Stroun studied the transfer phenomenon (referred to as transcession) in the early 1970s, observing that it was sufficient to inject only the supernatant of a bacterial culture into animals to promote the transcription of bacterial DNA in animal cells [108, 109]. By placing frog auricles in Ringer's salt solution, Anker and Stroun discovered frog nucleoprotein complexes (containing DNA, RNA, lipids, and DNA and RNA polymerases) in the extracellular medium [7, 9-11, 101]. In 1982, Adams and Gahan determined that all the elements of the nucleoprotein complex are synthesized together in the cells, with the exception of the RNA, which is transcribed in the cytoplasm just before the complex exits the cells [101]. These nucleoprotein complexes, later named virtosomes [15], share striking similarities with Bell's $I$-somes. Both consist of DNA released into the cytoplasm, forming complexes with proteins, RNA and RNA transcription machinery that transcribe RNA in the cytoplasm before the complexes exit the cells. The studies by Stroun, Stephen Pelc (discussed in "The discovery of DNA with metabolic activity" and "Metabolic DNA"), Bell, Anker, and Gahan have suggested that DNA in the cytoplasm of cells act as messenger DNA $[5,110,111]$, possibly explaining the cellular transformation occurrences observed by the multiple studies mentioned earlier [1, 2, 85-92], and providing one possible mechanism for the metastatic spread of cancer [27].

\section{The role of circulating DNA in disease}

Studies have indicated that diseases which cause endogenous tissue destruction, e.g., hepatitis, metastatic carcinoma, lupus erythematosus, and miliary tuberculosis, result in the increase of cirDNA levels [112-114]. Leon et al. [112] reported the presence of and quantified DNA in the serum of cancer patients. When compared with the healthy controls, $50 \%$ of cancer patients presented elevated serum DNA levels and there was a correlation between the persistence of the elevated serum DNA levels and the weak response to therapy. As mentioned in "DNA, heredity and the advent of extracellular DNA", mammalian cells can also take up DNA in vitro and in vivo [27, 93, 94]. With this in mind, Bendich et al.'s hypothesized that cirDNA could be involved in the metastatic spread of cancer [27]. Tumorigenic DNA can be transported in a biologically active form via the circulatory or lymphatic systems, resulting in the penetration of various tissues. The disintegration of cells in necrotic areas of actively growing tumors in animals also results in the release of both normal and tumor-specific DNA fragments into plasma and serum. García-Olmo and colleagues hypothesized in 1999 and confirmed in 2010 that the horizontal transfer of tumorderived cirDNA can transform NIH3T3 cells, producing cancerous cells [28, 115]. García-Olmo and colleagues referred to this hypothesis as the theory of genometastasis, the occurrence of metastasis via the transfection of susceptible cells, located in distant organs with dominant oncogenes that are derived from a primary tumor and are circulating in the plasma $[28,115,116]$. To date, there is no direct evidence that mutated cirDNA can initiate metastases. However, studies later confirmed that cirDNA (k-ras codon 12 mutated DNA) can promote tumor progression via lateral gene transfer (LGT) in rats that already have developed tumors, but does not itself initiate tumor formation in the host animal [117]. This concept of tumorigenic DNA being involved in cancer metastasis correlates so effectively with Darwin's gemmules that one cannot help but agree with Liu [118] that gemmules are analogues to cirNAs.

\section{The bystander effect}

The bystander effect refers to the effect of information transfer from targeted cells exposed to damaging agents of physical or chemical natures to adjacent, nonirradiated cells [119]. In 1984, Faguet et al. showed that cellular elements released clastogenic factors as a result of radiation effects, action, or cell damage, and Emerit et al. supported this finding in multiple studies in the 1980s and 1990s, identifying the factor(s) as low molecular weight (1000-10,000 Da) molecules that involved lipid peroxidation and oxidative stress in their production [120, 121]. It was also determined that patients with conditions, such as chronic inflammatory disorders or Fanconi's anemia, also had plasma with clastogenic activity [120]. Mothersill and Seymour also identified factors produced by irradiated cells and determined that these factors induced apoptosis and necrosis, reduced cloning efficiency, and induced proteins involved in the control of cell death in cells that were not 
exposed to radiation [121, 122]. Mothersill and Seymour [121] theorized that the identified factors were proteins, but Ermakov and colleagues later indicated that cirDNA also participates in the bystander effect induced by exposure to X-ray irradiation in human lymphocytes [123] and endothelial cells [30, 32], providing the possibility that Mothersill and Seymour's factors may have been DNA rather than protein.

\section{Lateral transfer of circulating DNA from healthy tissues}

The bystander effect and genometastasis show that cancerous and damaging effects or messages can be transferred from cell to cell via LGT. However, healthy tissues are just as capable of transferring information between cells [124]. Garcia-Olmo et al. [29] demonstrated that the virtosomes of healthy non-dividing cells can modify the biology of recipient dividing tumor cells, resulting in the halting of DNA synthesis and tumor development, the possible reduction in tumor size and the prevention of metastases. It has been recently proposed that there is selectivity involved in cirDNA release, which supports the idea of cirDNA having an intended function rather than merely being the consequence of cellular death or damage. The screening of multiple housekeeping genes released by cell lines into cell culture [125] revealed the unequal representation of cfDNA sequences cell cultures. Similar results have been presented in human blood in 2009 [126].

\section{The discovery of DNA with metabolic activity}

In 1944, Ahlstrom, Euler, and Hevesy [127] discovered an increase in DNA content unproportional to the increase of organ weight during the growth of newborn rats, proposing that the formation of some of the labelled DNA molecules was not due to the synthesis of new cells, but due to an increase in the DNA content of cells already present [127, 128]. At first, it was assumed that DNA turnover occurred along with the cell formation, resulting in the difference between the calculated and radioactive data. However, this was deemed to not be possible, since the renewal of DNA only took place in very special cases. Fourteen years later, Stephen Pelc observed a similar incorporation of labelled adenine into the nuclei of nondividing tissues. This was a significant finding, since DNA was considered to be stable in non-dividing tissues. He theorized that the synthesis or exchange of DNA took place in certain tissues as a metabolic function, unconnected with cell division, and that this metabolism was connected with the formation of certain proteins [129].
In 1959, Pelc questioned whether DNA might be broken down to a certain extent and reformed in cells and thought that this process should be detectable via the incorporation of DNA precursors in non-dividing cells or via the loss of DNA by processes other than pyknosis in dying cells. Pelc's autoradiographic studies of mouse seminal vesicles treated with colchicine indicated that the resulting incorporation of DNA precursors was considered at least 20 times above the requirement for cell division [130]. Mouse prostate cells showed a threefold excess of incorporation over that required for cell division. Feulgen-photometry of the cells during the study indicated that polyploidy was not responsible for the excessive DNA synthesis. Studies by Pelc and Gahan [131] showed similar results and it was hypothesized that all or most of the DNA contained in nuclei took part in metabolic activity that was unlikely to be connected with the genetic specificity of DNA.

In 1962, Pelc observed heavily and weakly labelled nuclei in the liver, smooth muscle surrounding the seminal vesicle, and interstitial cells of the testis of mice. It was assumed that the cells incorporated DNA precursors at different rates, producing the different levels of labelling [132]. There was no evidence of an immediate connection or direct connection between cells with weakly labelled nuclei and cells with heavily labelled nuclei. Pelc identified strong relationships between the presence of the weakly and heavily labelled nuclei to a similar occurrence observed by Ficq and Pavan [133], where considerable incorporation of tritiated thymidine into certain bands of polytene chromosomes of Rhynchosciara angelae occurred during the enlargement of the bands at certain steps of development. The "puffing" of the bands is due to a different activity of the genes at different times in the larval development and may occur similarly in the differentiated cells of mammalian organs. However, in differentiated cells, the same parts of chromosomes would be involved at all times, resulting in a lack of increase and decrease in the size of the chromosomal bands, as seen in $R$. angelae during different larval stages [134].

There were authors that could not identify any excessive DNA precursor incorporation or metabolic activity during their studies and some attributed Pelc's results to errors in methodology [135-137]. It was, however, possible that differences in the autoradiographic methods used (e.g., the use of the less reliable liquid emulsion technique versus the more reliable stripping film technique [138] and variations in the length of film exposure) contributed to these differences in results. In 1964, Pelc again determined that the incorporation of labelled thymidine in mouse seminal vesicles, heart muscle, and smooth muscle exceeded the requirements for cell division by a factor of eight to twelve [139] to refute results obtained by Gall and Johnson [136] who found that the incorporation of labelled thymidine was 
due to premitotic DNA synthesis. He did, however, admit that premitotic and nonmitotic DNA synthesis had certain features in common. He also showed that diurnal rhythms could not be responsible for the excessive labelling of the cells, which Gall and Johnson suspected could have influenced Pelc's earlier results. Pelc believed that his studies started to suggest a contradiction of the theories of synthesis and biological action of DNA. It appeared possible for the strands of double helix DNA to separate and for one strand to be utilized for the synthesis of new molecules, while the second strand was discarded, thereby retaining a true copy of a 2C amount of DNA [139]. Parts, or all, of the DNA could, therefore, be renewed by self-reproduction, whereby DNA could still act as a template. It could, therefore, be assumed that after some time, DNA can become unusable, similar to enzymes [139], as they are subject to wear and tear while active and must be periodically renewed.

\section{Metabolic DNA}

\section{Lima-de-Faria's DNA bodies and the origin of the term "metabolic DNA"}

The presence of DNA bodies in oocytes was identified in Dytiscus as early as 1901, with similar bodies found in multiple Tipula species during the 1930s and 1950s [140]. In 1962, Lima-de-Faria [141] used tritiated thymidine incorporation to determine whether DNA synthesis occurred in the DNA bodies of Tipula oleracea larvae and to study their metabolic behavior. He determined that the DNA body of a T. oleracea oocyte consisted of approximately $59 \%$ of the DNA of the whole nucleus. During diplotene, the DNA of the DNA body is suddenly released and becomes available to cellular components. Lima-deFaria compared the occurrence and disintegration of DNA bodies to the metabolic behaviour of the "puffing" of chromosomal bands observed in Rhynchosciara [133] and also associated the occurrence and disintegration of DNA bodies to the occurrence of DNA with metabolic activity observed by Pelc [130, 141]. He was aware of the scepticism that Pelc received regarding the metabolic activity of DNA by Gall and Johnson [136], but believed that the occurrence of both the "puffing" chromosomal bands and the DNA bodies served as sufficient evidence to support Pelc and Gahan [131] 's hypothesis that all or most of the DNA contained in nuclei took part in metabolic activity that was unlikely to be connected with the primary function of DNA [141]. Gall and Johnson [136] were the first to refer to Pelc's DNA with metabolic activity as "metabolic" DNA, but their continuous use of scare quotes for this term illustrates their scepticism regarding its appropriateness.
Lima-de-Faria was, in fact, the first to officially use the term metabolic DNA and the first to propose that metabolic DNA could serve as information carriers, as the released DNA of disintegrated DNA bodies could carry its own information to other cellular components [141].

\section{The contents of DNA bodies}

Lima-de-Faria and Moses studied DNA bodies in the females of the fly Tipula oleracea that formed in contact with the sex chromosomes in the oogonial interphases [142]. A DNA body synthesizes its DNA at a different time to that of the chromosomes, and its DNA forms complexes with histones, similar to the DNA of the chromosomes. At late diplotene, the DNA body disintegrates and its DNA is released into either the nucleus or the cytoplasm [142], similar to the destruction of macronuclei in ciliated protozoa (see "Macronuclei and metabolic DNA") after the micronuclei underwent division or meiosis [143-145]. The nucleoli of the Tipula oocytes are positioned within the DNA body and the presence of a band of RNA between the body and the chromosomes was detected, indicating that the DNA body has high RNA synthetic activity. Due to the positioning of nucleoli in the DNA body and the fact that the DNA of the body is complexed with histones, it was interpreted that the DNA body represents hundreds of copies of the operons of the nucleolar organizing region or neighboring regions.

DNA and RNA synthesis in DNA bodies during the different phases of meiosis

In 1968, Lima-de-Faria et al. [140] studied the DNA and RNA synthesis in the DNA bodies of Acheta domesticus oocytes (Fig. 4). Every female oocyte contains a DNA body, but no DNA bodies of comparable size or shape are present in the male meiotic prophase. Similar to T. oleracea, the DNA of the DNA bodies is synthesized at a different time to that of the chromosomal DNA and is complexed with histone, indicating that the bulk of DNA synthesis occurs in the DNA body.

The DNA body's DNA mass reaches its maximum at the beginning of the meiotic prophase and the chromosomes have been found to contract during this period. At pachytene and diplotene, the DNA body acquires the appearance of a puff, similar to the chromosomal puffs found in the polytene chromosomes of $R$. angelae [133] (Fig. 4). DNA synthesis within the DNA bodies ceases during the late pachytene and diplotene and the DNA body begins to disintegrate at the end of diplotene, breaking up the core into minor components and disintegrating the outer RNA shell. By late diplotene, the whole body is gone, releasing DNA, histone, and RNA into the nucleus with subsequent 


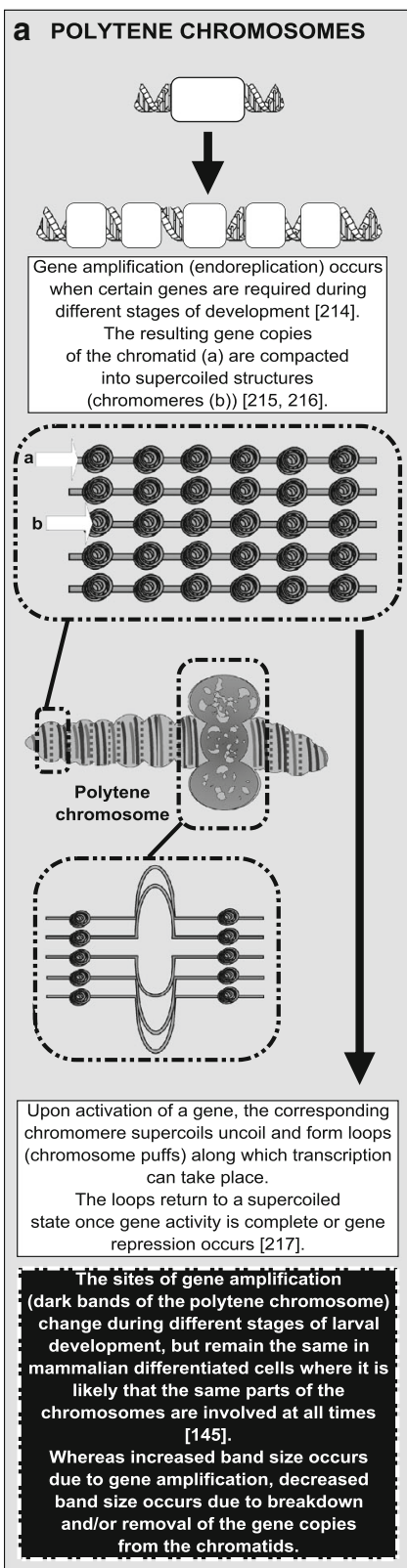

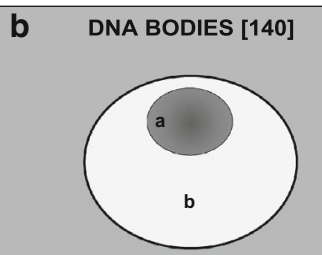

The nucleus of an Acheta domesticus oocyte at interphase containing a large Feulgen positive DNA body (a) an chromosomal DNA (b).

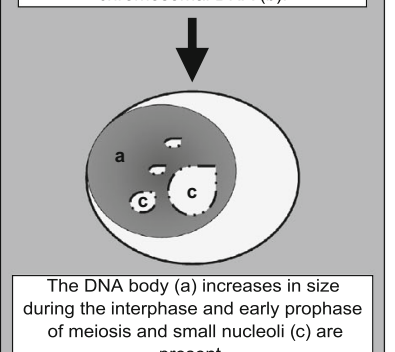
of meiosis and small nucleoli (c) are

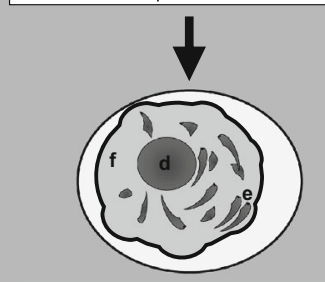

At pachytene and diplotene the DNA body develops a "puff"-like appearance with two distinguishable zones: An inner core of DNA (d) which form fibrils (e) that radiate outward toward an outer shell ofRNA (f).

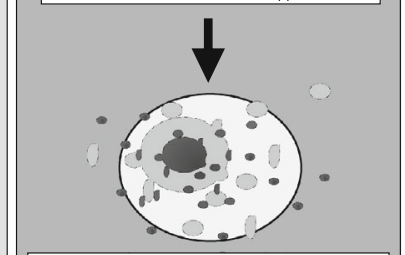

At the end of diplotene the DNA body and RNA shell begin to disintegrate and $b y$ late diplotene the DNA body is gone. This disintegration results in the sudden release of DNA, RNA and histonesinto either the nucleus or other cellular components.

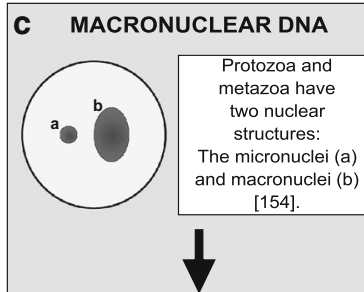

Macronuclei consist of metabolic DNA formed by multiple replications from the genetic DNA of the micronuclei and by self-replication and are responsible for ranscribing RNA required for the metabolic functions of the cell [154].

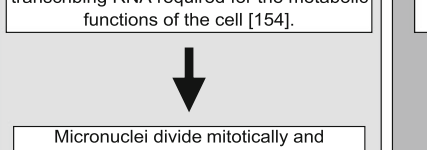

macronuclei divide via amitosis. After conjugation or autogamy, micronuclei undergo meiotic and post-meiotic divisions, whereas macronuclei are broken down and resynthesized. The destruction and resynthesis of macronuclei ensure that the

DNA of the macronuclei remains similar to the genetic DNA of the micronuclei, which could have changed during division

$$
\text { which could have changed }
$$

\section{(}

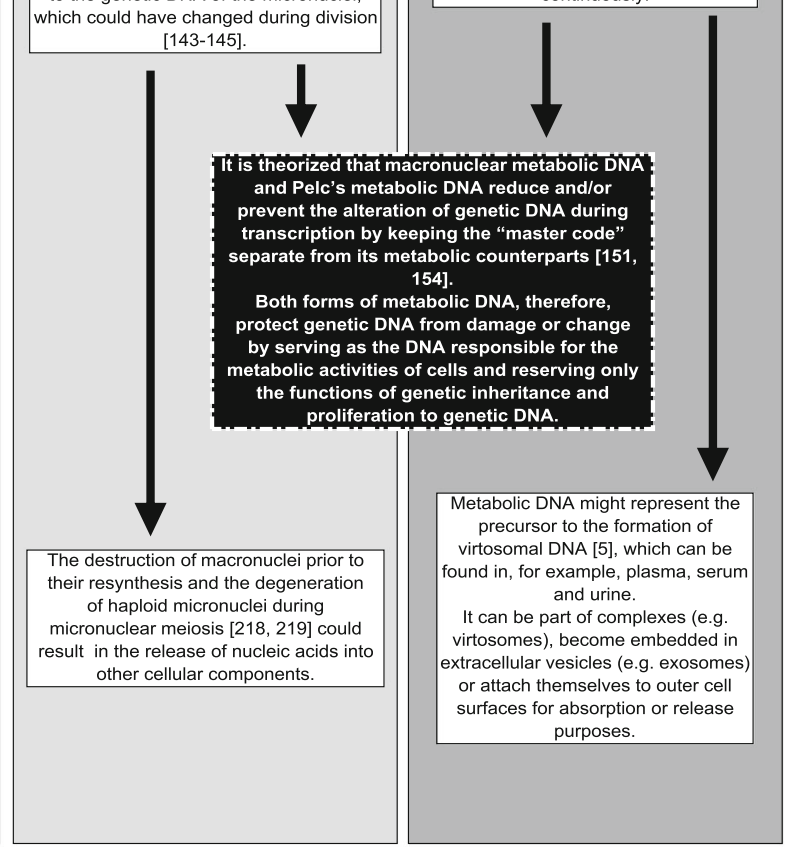

[140, 141], theoretically making Lima-de-Faria not only the first to officially use the term metabolic DNA, but also the first to connect metabolic DNA to genetic messaging and cirNAs. c Pelc connected metabolic DNA with the macronuclear DNA of ciliated protozoa in 1970, giving reason to believe that metabolic DNA served a similar protective purpose towards genetic DNA as macronuclear metabolic DNA would protect micronuclear genetic DNA from alterations during transcription [156-161]. d Schematic summary of key characteristics of Pelc's metabolic DNA which share striking similarities with macronuclear metabolic DNA. The breakdown or removal of copied genes from polytene chromosomes during the larval development, the release of DNA and RNA from DNA bodies during disintegration, and the regular degeneration of old macronuclei and synthesis of new macronuclei during meiosis result in the release of nucleic acids into the nucleus, cell, and circulation, indicating a connection between Pelc's metabolic DNA and cirNAs as suggested by Lima-de-Faria [141] and later by Gahan et al. [5]
1968 and proposed that the DNA released during the disintegration of the DNA body at the end of diplotene serve as information carriers 
disintegration of the nuclear envelope at the end of prophase in meiosis. The DNA body forms two distinctive zones, an inner core of DNA, and an outer shell of RNA. The inner core forms Feulgen positive fibrils that radiate into the outer RNA shell, producing the appearance of the puff. RNA synthesis occurs in the outer RNA shell and in the chromosomes. Similar to the DNA bodies of T. oleracea, Lima-de-Faria et al. [140] have determined that the DNA body represents hundreds of copies of the genes of the nucleolar organizing region.

\section{Pelc's metabolic DNA}

Michael James Sampson identified two forms of DNA in Vicia faba, wheat, corn, and barley, namely high and low molecular weight DNA [146-148]. There was no evidence for turnover of the high molecular weight DNA, and this DNA also showed the same composition, irrespective of the tissue of origin, indicating that high molecular weight DNA in higher plants behaved typically as genetic material [147]. The metabolically labile, low molecular weight DNA of nuclear origin, however, was considered to have a physiological role rather than genetic due to its rapid formation in embryos induced to germinate [146, 147]. DNA synthesis detected during the period, in which ${ }^{32} \mathrm{P}_{\mathrm{i}}$ was administered to barley roots, was that of the low molecular weight DNA [148]. The specific activity of high molecular weight DNA in barley roots labelled with ${ }^{32} \mathrm{P}_{\mathrm{i}}$ was similar in both dividing cells and cells in which mitosis was inhibited. Metabolically, labile newly synthesized DNA was detected in the non-dividing cells that resembled the low molecular weight DNA of the dividing cells. It appeared that part of the newly synthesized low molecular weight DNA existed hybridized with the high molecular weight DNA [148]. In 1966, Sampson and Davies studied the synthesis of metabolically labile DNA in $V$. faba root cells. Autoradiography of labelled cells showed that the greater part of all thymidine incorporated into DNA was located in the nucleus. The region of cell elongation was also observed to contain both more nuclei and more heavily labelled nuclei than the mitotic zone, which corresponded with studies conducted by Pelc and La Cour on newly differentiated nuclei of $V$. faba roots in 1959, where intense labelling was observed in approximately $25 \%$ of cells at a distance of 3-5 mm behind the $1.5-2 \mathrm{~mm}$ of meristem [146]. The similarities between Sampson's low molecular weight DNA and Pelc's DNA with metabolic activity suggested that they could be the same.

In 1967, Stroun et al. published an article, where the high and low molecular weight DNA fractions of mouse heart, skeletal muscle, and intestine were investigated. A low molecular weight fraction (between $5 \times 10^{5}$ and $4 \times 10^{6}$ ) and high molecular weight fraction (above
$4 \times 10^{6}$ ) were obtained [149]. The specific activity of the low molecular weight fractions was significantly higher than that of the high molecular weight fractions in the three organs. Stroun et al. [149] theorized that the high specific activity of the low molecular weight fraction, especially in non-dividing muscle tissue, was possibly due to this DNA existing as a separate fraction in mammalian cells, and connected this DNA to the DNA responsible for the metabolic activity observed in the previous studies by Pelc, and referred to it as metabolic DNA. Pelc summarized the characteristics of metabolic DNA in 1968: It has been determined that (a) stable and metabolic DNA existed in cells of higher organisms; (b) metabolic DNA is formed immediately after the last mitosis in some organs and may be synthesized during or immediately after premitotic synthesis but before mitosis; (c) metabolic DNA is renewed or repaired periodically instead of continuously; (d) metabolic DNA is closely connected with the functional activity of differentiated cells; and (e) changes in DNA content, incorporation of precursors, or loss of labelled DNA correlates with a definite stage in development or with the stimulation of activity, indicating a definite correlation of metabolic DNA with function [150, 151]. The following hypothesis on metabolic DNA has been suggested by Pelc [151]: the metabolic DNA of a given type of differentiated cell consists of extra copies of active genes in the cell; metabolic DNA is the working DNA involved in the regulation and performance of RNA production, and possibly, other functions of DNA; metabolic DNA molecules are subject to wear and tear while active and are periodically renewed; DNA can, therefore, be labelled during premitotic synthesis, metabolic DNA formation, and metabolic DNA renewal or repair [150, 151]. Figure 5 summarizes the series of above-mentioned experiments that led to the hypothesis of Pelc's metabolic DNA.

The plant studies of Pelc and Sampson were mainly limited to root tissues behind the meristem, tissue which have different metabolic properties, and might not represent physiological homogeneous tissue [152]. Studies by Hurst et al. [152] and Hurst and Gahan [153] demonstrated via colchicine treatment that the use of shoot tissues, particularly collenchyma, could offer distinguishable, functionally differentiated and non-dividing tissues to efficiently study the presence of metabolic DNA. ${ }^{3} \mathrm{H}$-thymidine (3H-Tdr) treatment and autoradiography of Lycopersicon esculentum shoots showed that the label was freely and equally available throughout the cells and that the tissues were seemingly heterogeneous, due to the presence of three different groups of collenchyma nuclei (no, low, and high levels of 3H-Tdr incorporation) after the isotope pulse. Hurst et al.'s [152] experiments proposed the following: (1) lack of change in mitotic activity in collenchyma tissue indicated that premitotic DNA synthesis 
did not occur during the experiments and was not responsible for the incorporation of label into genetic DNA; (2) gradual loss of label in the collenchyma indicated that polyploidy was also not involved unless genetic DNA degradation occurred after the tissues became senescent (the loss of label would, however, not be gradual if that was the case); (3) if the observed labelling occurred due to the repair of a portion or portions of the DNA, it would indicate that the "repaired proportions" of the DNA were degraded again; and (4) if there was no indication of total DNA variation or increased strand breakage, metabolic DNA synthesis (and gradual turnover after acting as a transcriptional unit within these differentiated tissues) would be strongly indicated. The biological half-life of any metabolic DNA fractions in the shoot tissue was determined to be approximately 6 weeks, which is considerably longer than that of $V$. faba roots $(24 \mathrm{~h})$ [146]. These differences were proposed due to species differences or differences in the functions and metabolic requirements of these tissues.

\section{Macronuclei and metabolic DNA}

Studies regarding the nuclear behaviour of various protozoa and metazoa occurred since the late 1800s. These organisms were found to have two different nuclear structures, micronuclei and macronuclei [154]. The micronuclei consist of the genetic DNA of the organism involved in inheritance and cell division, and remain otherwise inactive. Macronuclei consist of metabolic DNA formed by multiple replications of the genetic DNA and by self-replication, and are responsible for transcribing RNA required for the metabolic functions of the cell [154]. In 1970, Pelc described connections between the macronuclear DNA of ciliated protozoa [143, 144, 154] and metabolic DNA [145] (refer to Fig. 4): (1) both macronuclear and metabolic DNA are observed as separate forms of DNA from their nuclear or genetic counterparts (the genetic DNA from micronuclei and stable, high molecular weight DNA, respectively); (2) both have been described to consist of multiple copies of either the genetic DNA or parts thereof; (3) both have been theorized to be involved in RNA production required for the metabolic functions of cells; (4) for micronuclei and macronuclei, DNA synthesis occurs at two different time intervals before vegetative DNA division can occur. The micronuclei divide mitotically and the macronuclei divide via amitosis [143-145, 155]. Metabolic DNA is formed before/immediately after the last mitosis or during/immediately after premitotic synthesis, depending on the organ; (5) when micronuclei undergo meiotic and post-meiotic divisions, the macronuclei are broken down and resynthesized. The destruction and resynthesis of the macronuclei result in the
DNA of the macronuclei being similar to the genetic DNA of the micronuclei, which could have changed during division. A similar form of periodic renewal has been proposed for metabolic DNA; and (6) both have the potential to result in the release of DNA into the circulation. The destruction of macronuclei prior to their resynthesis could result in the release of nucleic acids into the extracellular space, and metabolic DNA has been proposed to represent the precursor to the formation of virtosomal DNA, which is released by cells into the circulation.

The similarities suggested that metabolic DNA could serve similar functions in higher organisms than that of the macronuclear DNA of protozoa and metazoa. The multiple copies of active genes of macronuclear and metabolic DNA may serve as a form of gene amplification, resulting in a higher rate of RNA production during the periods of high demand [151]. It has also been theorized that protozoa and metazoa have two separate forms of nuclei to reduce and/or prevent the alteration of DNA during transcription by keeping the master code separate from its metabolic counterparts. DNA damage, for example, can lead to the misreading or the presence of unsuitable molecules during transcription. Permanent cell damage may, therefore, occur if the gene copies of genetic DNA were directly involved in transcription. Multiple replaceable gene copies, on the other hand, are substituted through resynthesis if damaged. Thus, reducing the transcriptional involvement of the genetic DNA, by providing separate gene copies for these tasks in the form of macronuclear DNA, reduces the risk for accumulating genetic DNA damage or changes. To date, it has become evident that there are extremely high levels of regulation involved during transcription to prevent errors from occurring and whether metabolic DNA forms part of these regulation mechanisms is uncertain. This protection theory of macronuclei, however, does not account for the involvement of environmental factors in DNA damage, as the extra copies of DNA in separate nuclei would not be able to protect "dormant" genetic DNA from external factors.

\section{The characterization of circulating DNA}

Stroun et al. [156] were the first to characterize plasma DNA. CirNAs are detectable in various other fluids, including in serum, liquor, sputum, ascites, gastric juices, urine, bone marrow aspirates, stool samples, milk, lymphatic fluids, peritoneal fluids, cerebrospinal fluid, bronchial lavage, prostatic fluid, and biliary juices $[3,157,158]$. The generation of cirDNA, its accumulation in tissues, and elimination from the organism influences the concentration of DNA in circulating blood. Factors that 


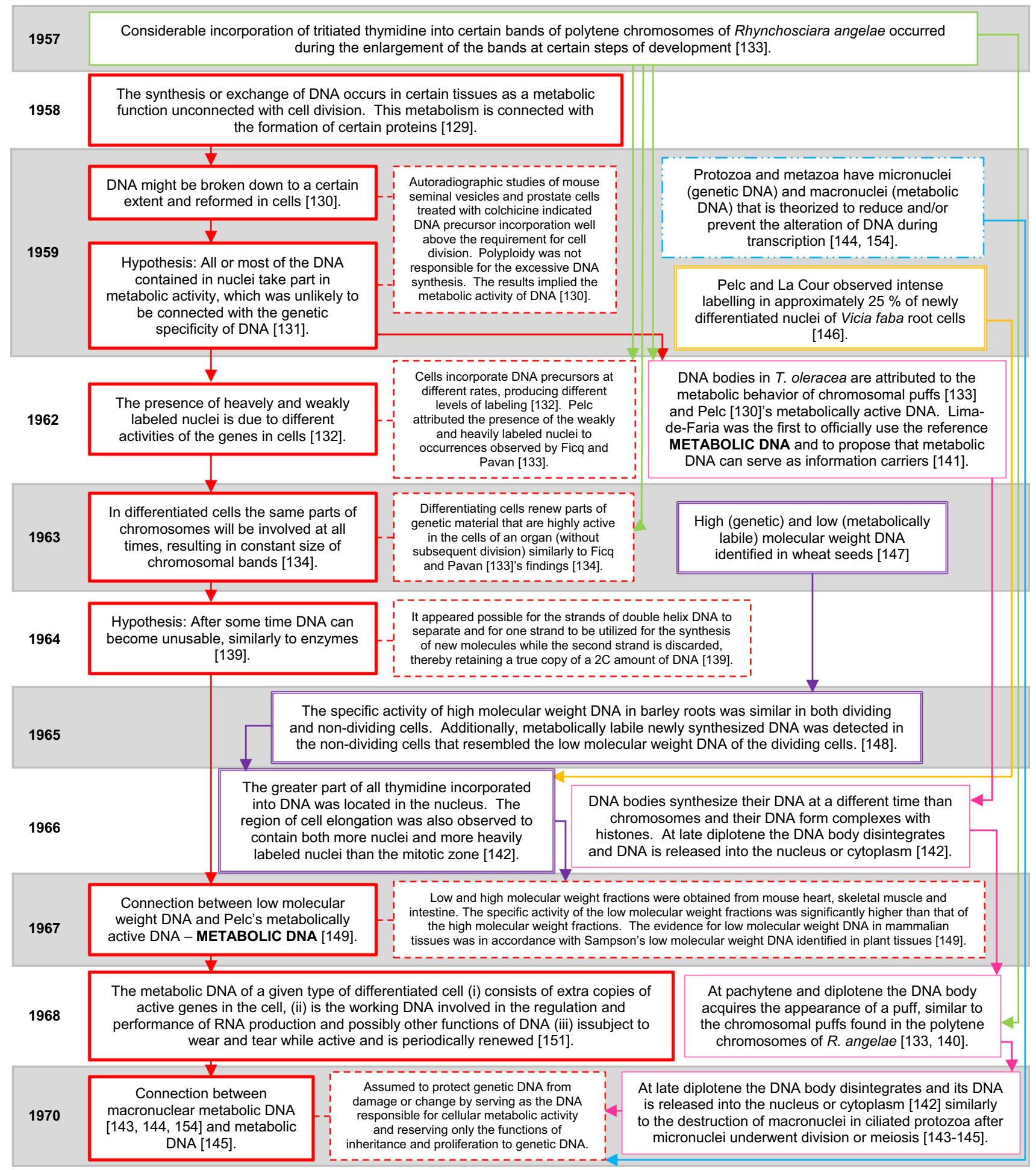

Fig. 5 Series of studies that influenced Pelc's research on metabolically active DNA and the development of Pelc's hypothesis on metabolic DNA

affect the circulation of cirDNA in the blood can include the activity of DNA-hydrolyzing enzymes in blood and tissues, the DNA's structure, and DNA-protein interactions in the blood [159]. CirDNA can be double stranded and single stranded $[6,7,112,156,160,161]$, is of low molecular weight, and is resistant to RNase and proteinase $\mathrm{K}$ [156], but can be hydrolyzed by DNase I, and is cleared predominantly by the liver and, to a lesser extent, the 
kidneys [162, 163]. CirDNA has also been found to have a high background of overall methylation in healthy people, which can increase the stability of cirDNA, allowing it to circulate in the blood stream for a longer time [159]. CirDNA can be released by both dividing and non-dividing, differentiated cell populations [5]. Their fragment sizes typically range from $100 \mathrm{bp}$ to $21 \mathrm{kbp}$ [156, 164, 165], where the short fragments can be related to the histone octamer structure and apoptosis, while the longer fractions originate from necrotic cells [165]. A high proportion of the cirDNA originating from tumors, however, are more fragmented than that of healthy tissues, releasing DNA fragments smaller than $100 \mathrm{bp}[6,166]$. Recently, we have reported a size of $2000 \mathrm{bp}$ for the cfDNA of osteosarcoma cell cultures [167]. CfDNA samples-containing only these fragments showed no flow cytometric detection of apoptosis and necrosis, indicating that the $2000 \mathrm{bp}$ cfDNA may be a product of active release.

\section{Extracellular vesicles and mobile protein complexes}

CirDNA is predominantly conveyed throughout the body in extracellular vesicles (EVs). These vesicles are generally categorized as exosomes, microvesicles (MVs), and apoptotic bodies (ABs). All of the formers have not yet been rigorously characterized, and, therefore, still remain poorly understood in terms of function [168-171]. EVs are categorized mainly on the grounds of their size and origin. Exosomes are classified as being 40-100 nm in diameter and are released due to fusion of multivesicular endosomes with the plasma membrane [172]. MVs, on the other hand, range between 100 and $1000 \mathrm{~nm}$, whereas $\mathrm{ABs}$ can be as big as 4000-5000 nm. MVs and ABs, unlike exosomes, are shed from the plasma membrane [173]. There is, however, some confusion in the literature regarding nomenclature. This stems from three independent factors, namely: (1) most purification regimes cannot completely differentiate between the different EVs; (2) cells release a heterogeneous population of EVs [174-176], and (3) there is an overlap in the category of size. For instance, prostasomes (also classified as exosomes) have been documented to range between 40 and $490 \mathrm{~nm}$ [177], and some microvesicles have the same sizes as exosomes [178]. In the previous work, we have demonstrated that centrifugation time and speed influence the yield of cfDNA isolated from cell culture media [179]. These factors collectively contribute to the difficulty to reach a consensus on structural definitions. Except for EVs, CirDNA can be part of protein complexes or attach themselves to binding proteins or phospholipids on outer cell surfaces for absorption or release purposes [15, 167, 180-182]. CirDNA can also be in the form of mitochondrial DNA and nucleosomes as a result of apoptotic processes [182, 183]. In this paper, we will only focus on exosomes and protein complexes.

\section{Exosomes}

Exosomes are intraluminal vesicles secreted by cells consequential to the intracellular fusion of multivesicular bodies with the plasma membrane [158]. Although exosomes were discovered more than three decades ago, they were not given much attention due to a preconception that they were mere cellular waste disposal systems [184]. This view has changed once proteomic analysis showed that exosomes contain several proteins that are implicated in intracellular membrane transport, cell signalling, and apoptosis [185]. In the pursuing years, it has become apparent that exosomes act as haulers that convey an assemblage of cell-specific proteins and genetic material to other cells [184]. They have been shown to contain only RNA [186], only DNA [187], or sometimes both [188]. Interestingly, cancer tissue-derived exosomes have been shown to contain genomic DNA spanning all chromosomes. This information can be used to determine genomic DNA mutations that will be of diagnostic, prognostic, and theranostic value [189-192]. In any case, the selective packaging of specific nucleic acids into tailor made vesicles indicates a specialized function. Indeed, many publications have associated them with the messenger functions of various natures, such as the induction of tolerance against antigens, eradication of established tumors in mice, promotion of differentiation into T-regulatory cells, and adaptive recruitment against oxidative stress [25]. Furthermore, the composition and function of exosomes depend on the characteristics of the cells from which they originate and the conditions under which they are produced (toxic, oxidative stress, hyperglycaemia, for example) [24].

Ronquist et al. [177] discovered prostasomes in human prostatic fluid and seminal plasma. These vesicles were equivalent to exosomes from other cell types in that they were produced and secreted in the same manner [193]. The name "prostasome" exemplifies the cell type from which it originates (namely prostate cells), whereas "exosome" denotes the family name [194]. Further studies have shown that prostasomes can interact with spermatozoa [35]. This finding was met with greater enthusiasm when Ronquist et al. [36] discovered that prostasomes contain small fragments of DNA that seem to represent random parts of the entire genome. Two years later, Ronquist et al. [33] went on to demonstrate that these fragments of DNA could be taken up by sperm cells. Although, in the same year, Ronquist synthesized many examples of the intercellular messaging functions of prostasomes [195], he previously 
stated his uncertainty regarding the extent of its biological functions [36]. In 2011, Ronquist stated that, at that point in time, there were no reports that indicated the presence of RNA in prostasomes [195]. Later that year, however, Hessvik et al. [196] demonstrated that exosomes derived from both non-cancerous (RWPE-1) and cancerous (PC-3) prostate cell lines did, in fact, contain miRNAs. Very interestingly, they found that, although the miRNA profiles of exosomes from both cell lines were very similar to that of their corresponding parental cells, there was a moderate amount of sorting involved. For instance, the PC-3-derived exosomes contained much less low number miRNAs than their parental cells. Moreover, although also with very similar profiles, some miRNAs were differentialy expressed between the two different cell lines. This selective sorting of miRNAs is surely a salient feature, but we will not elaborate on it in this review. However, here, we can speculate that prostasomes may have the ability to convey adaptive genetic and epigenetic changes, which the soma has undergone, to the sperm cells. The packaging of nucleic acids in EVs likely promotes its uptake into cells, and protects it from nuclease and nucleic acid-binding proteins present in the seminal vesicles, which is believed to facilitate the direct uptake of nucleic acids by sperm cells [197].

Recent findings of Cosetti et al. [34] confirm that exosomes can be involved in soma-to-germline information transfer, showing that human melanoma cells xenografted into mice released RNA which was transported through the bloodstream via exosomes and eventually into spermatozoa, implicating exosomes, carriers of cirDNA, in the heredity of acquired changes. This possibility is also demonstrated by another landmark study, in which it was demonstrated that exosomes can traverse physical barriers and affect the biology of another cell [197, 198].

\section{Mobile protein complexes}

So far, the predominant view is that cirDNA is only transported throughout the body via EVs. There is, however, substantial evidence that protein complexes can do the same. Indeed, it has been reported that $90 \%$ of circulating miRNAs are not associated with EVs. Here, we will briefly discuss three types of protein complexes that have been described in the literature, namely virtosomes, highdensity lipoprotein (HDL), and argonaute2 (Ago2). Virtosomes were the first protein nucleocomplexes to be described ("The concept of transcession"). Virtosomes have been demonstrated to be composed of both DNA and RNA. They have also been shown to be actively released by all living cells studied to date, but not dead or dying cells, and have the ability to enter recipient cells, followed by incorporation of the DNA into the genome. The DNA content has been demonstrated to hybridize with nuclear DNA, and thus bears great similarity to cellular DNA. The type of RNA present has not yet been determined, but it has similar effects on recipient cells than that of siRNA or miRNA [15]. Liposomes, containing apolipoprotein A-I, have many times been used as an artificial vehicle to deliver small interfering RNAs to target animal cells. Interestingly, apoA-I is the main constituent of HDL. Based on this fact, and, keeping in mind, the knowledge that HDL interacts with nucleic acids, Vickers et al. [199] hypothesized that HDL could be associated with endogenous miRNAs. Not only did they demonstrate this, but they have also shown that HDL can deliver miRNAs to target cells with gene regulatory consequences. HDL could evidently play a role in intercellular messaging. Ago2 is commonly known as the key effector protein of gene silencing mediated by miRNA. Arroyo et al. [200] then discovered Ago2 in human plasma, but have also demonstrated that it is associated with miRNA. They have also found that miRNA is much more stable when associated with Ago2. After demonstrating that the liver-specific miRNA miR-122 was released only in the form of lipoprotein complexes, Arroyo et al. hypothesized that Ago2-miRNA complexes reflected the biology of the cells from which they originated. This suggests that cells purposely secrete functional miRNA gene silencing complexes into circulation, possibly to convey intercellular messages.

\section{Discussion and conclusion}

Natural selection and IAC are the two principle schemes devised to explain evolution. After decades of scrutiny, the majority of scientists subscribe to the idea that evolutionary change occurs through the guidance of selective processes, and not IAC. However, Darwin himself believed in IAC and formulated the hypothesis of Pangenesis to account for it. This does not mean that he disregarded random variations, indeed, he considered IAC to be an auxiliary mechanism to natural selection [201]. In Darwin's era, however, there was a lack of interest to elucidate the mechanisms implied by Pangenesis and IAC, which guaranteed the position of IAC and Pangenesis in the garbage pail of history. However, in this review, we present ample evidence that acquired characteristics can, indeed, be inherited, and also show that this process seems to be governed by rules that undermine the basic assumption that variation is random [202]. Thus, it is has become clear that, although their ideas seem naive today, Darwin and Lamarck were not entirely wrong. In the present-day genetics terms, IAC and Pangenesis imply that an environmental factor can induce genetic and epigenetic changes 
in targeted sites, which, in turn, allows adaptation to the original factor of invocation, and that this new information can be transferred to neighboring cells, germ cells, and the next generation of offspring. Contemporary molecular genetics shows us that this happens quite often, and many different mechanisms are involved.

First, it has generally been assumed that all the somatic cells of a higher organism contain an exact replica of the entire genetic code, and that it is subject to change only by virtue of random mutations due to replication errors and inevitable damage to the genome. In contrast, there is a great deal of evidence, indicating that the genome is continuously formatted by directed rearrangements and inscriptions (for a comprehensive review, refer to [203]). This is corroborated by Astolfi et al. [204] who presented substantial experimental and theoretical evidence that the cells of higher organisms are a mosaic of genetic variants. This is owed to the fact that individual organs, tissues, and cells are vulnerable to environmental stress under the localized conditions, allowing them to generate genetic diversity. One of the best examples we could elaborate on is gene duplication, which is well known to be a major source of genetic variation for normal non-cancerous cells. In 1978, Biedler and Spengler found that cultured mammalian cells implemented selective gene duplication as a mechanism for acquiring resistance to methotrexate (MTX) [205, 206]. Subsequent studies then established that gene amplification could be utilized as a mechanism for resistance to other toxic chemicals as well. Since then, gene duplication has been found to be a rather common phenomenon under selective pressure [207]. Interestingly, quite rapidly after gene duplication, the copy starts to gradually accumulate mutations, causing the parent and duplicate genes to diverge. This divergence may result in (1) non-functionalization, wherein either one of the copies are silenced; (2) neofunctionalization, wherein one copy develops a novel function, but the other remains normal, and (3) subfunctionalization where both copies obtain complementary functions that, together, perform the original function. It appears to be a general rule that gene expression is modified, and relatively quickly, after gene duplication. Indeed, results presented by Aldana et al. [208], indicate that duplication and diversification of a single gene could result in the emergence of novel phenotypes and, subsequently, the reconfiguration of gene expression pathways (refer to [208] for a more detailed description).

The benefit of genetic variation is exemplified by numerous studies showing that prokaryotes borrow genetic ideas from one another, allowing adaptation to toxic substances. Similarly, the implication of somatic genome variation in higher organisms is that, although it may, in some cases, compromise normal cellular functions (as seen in cancer metastasis, for example), it creates new coding and regulatory sequences. This may offer many new capabilities to pre-existing frameworks. In a comprehensive synthesis, Koonin and Wolf [46] showed that HGT is a major component of Lamarckian evolution. Ever since comparative genomics has revealed the ubiquity of HGT in prokaryotes and unicellular eukaryotes, the phenomenon has been avidly documented. However, the evidence indicating that lateral gene transfer occurs between different cells within one organism, including humans, has not been given adequate attention and is still very poorly characterized. Similar to prokaryotes, is it conceivable that the genetic variants created in specific somatic cells in higher organisms are receptive to intraorganismal Darwinian selection? It is likely that this is a common phenomenon, but has been occurring mostly unnoticed. This could be due to the difficulty to trace adaptive responses in non-pathogenic events. We propose that these genetic variants are shared between cells by the transference and transfectionlike uptake of cirDNA in the form of EVs and protein complexes. However, the elucidation of this phenomenon is thus far complicated primarily by a lack of understanding, regarding the origin and biological functions of cirDNA. We argued that many, and, perhaps, some crucial, answers to these questions are well hidden in the literature of the past. For this reason, we reconstructed the historical path that led to the discovery and concepts of cirDNA and EVs. From this, we learned that the discovery of cirDNA and EVs can be traced backed to the ancient Greek philosophers, and it is clear that it is tightly interwoven with some of the most prominent discoveries in heredity, genetics, and evolution. Today, there is a lot of evidence that cirDNA deliberately, genetically, and epigenetically alters the biology of recipient cells and that this is strongly implicated in the progression of several diseases, immunomodulation, cell differentiation, adaptation, and transgenerational genetic and epigenetic inheritance.

We also presented evidence indicating that metabolic DNA may be the precursor to the bulk of cirDNA. With this in mind, the following three characteristics of metabolic DNA can provide important clues that can help elucidate the origin of cirDNA: (1) there are two types of DNA existing in the cells of higher organisms, namely the stable high molecular weight DNA and the low molecular weight fraction of DNA, which are renewed periodically rather than continuously (indicating exposure to wear and tear); (2) metabolic DNA synthesis occurs at different times than the stable genetic DNA (before or after mitosis); and (3) the content of metabolic DNA represents multiple copies of genes that correlate with a definite stage in development or with the stimulation of an activity, indicating a definite correlation of metabolic DNA with cellular function. Metabolic DNA is, therefore, considered 
as specially synthesized DNA that serve as the working DNA involved in the regulation and performance of RNA production and other DNA functions. In other words, the occurrence of cirDNA is not just the result of cell lysis and apoptosis that can affect neighboring cells, as many tend to believe, but is newly synthesized and complexed with lipoproteins or packaged in vesicles specifically to serve as messengers. Furthermore, the tailor made EVs and protein complexes that facilitate the transfer of cirDNA between cells are also capable of transporting cirDNA to sperm cells. This is very similar to the idea that Darwin had in mind when he suggested the existence of gemmules. CirDNA may thus have a special role in adaptation, transgenerational inheritance, and by implication, evolution.

Acknowledgments The authors would like to thank Peter B. Gahan for professional assistance with this review article. AJB (SFH13092447078) and JA (SFH14061869958) were supported by post-graduate scholarships from the National Research Foundation (NRF), South Africa. The financial assistance of the NRF is hereby acknowledged. Opinions expressed and conclusions, arrived at, are those of the authors and are not necessarily to be attributed to the NRF.

\section{References}

1. Griffith F (1928) The significance of pneumococcal types. J Hyg 27:113-159

2. Avery OT, MacLeod CM, McCarty M (1944) Studies on the chemical nature of the substance inducing transformation of pneumococcal types induction of transformation by a desoxyribonucleic acid fraction isolated from pneumococcus type III. J Exp Med 79:137-158

3. Fleischhacker M, Schmidt B (2007) Circulating nucleic acids (CNAs) and cancer-a survey. Biochim Biophys Acta 1775:181-232

4. Mandel P, Métais P (1948) Les acides nucléiques du plasma sanguin chez l'homme [The nucleic acids of blood plasma in humans]. Compte Rendu de l'Academie des Sciences 142:241-243

5. Gahan PB, Anker P, Stroun M (2008) Metabolic DNA as the origin of spontaneously released DNA? Ann NY Acad Sci 1137:7-17

6. Thierry AR, El Messaoudi S, Gahan PB, Anker P, Stroun M (2016) Origins, structures, and functions of circulating DNA in oncology. Cancer Metastasis Rev. doi:10.1007/s10555-0169629-x

7. Anker P, Stroun M, Maurice PA (1975) Spontaneous release of DNA by human blood lymphocytes as shown in an in vitro system. Cancer Res 35:2375-2382

8. Borenstein S, Ephrati-Elizur E (1969) Spontaneous release of DNA in sequential genetic order by Bacillus subtilis. J Mol Biol 45:137-152

9. Stroun M, Anker P (1972) Nucleic acids spontaneously released by living frog auricles. Biochem J 128:100

10. Stroun M, Anker P (1972) In vitro synthesis of DNA spontaneously released by bacteria or frog auricles. Biochimie 54:1443-1452
11. Stroun M, Anker P, Gahan P, Henri J (1977) Spontaneous release of newly synthesized DNA from frog auricles. Arch Sci 30:229-241

12. Stroun M, Anker P, Beljanski M, Henri J, Lederrey C, Ojha M, Maurice PA (1978) Presence of RNA in the nucleoprotein complex spontaneously released by human lymphocytes and frog auricles in culture. Cancer Res 38:3546-3554

13. Bulicheva N, Fidelina O, Mkrtumova N, Neverova M, Bogush A, Bogush M, Roginko O, Veiko N (2008) Effect of cell-free DNA of patients with cardiomyopathy and rDNA on the frequency of contraction of electrically paced neonatal rat ventricular myocytes in culture. Ann NY Acad Sci 1137:273-277

14. Ermakov AV, Kostyuk SV, Konkova MS, Egolina NA, Malinovskaya EM, Veiko NN (2008) Extracellular DNA fragments. Ann NY Acad Sci 1137:41-46

15. Gahan PB, Stroun M (2010) The virtosome-a novel cytosolic informative entity and intercellular messenger. Cell Biochem Funct 28:529-538

16. García-Olmo DC, Ruiz-Piqueras R (2004) Circulating nucleic acids in plasma and serum (CNAPS) and its relation to stem cells and cancer metastasis: state of the issue. Histol Histopathol 19:575-583

17. Skog J, Würdinger T, van Rijn S, Meijer DH, Gainche L, Curry WT, Carter BS, Krichevsky AM, Breakefield XO (2008) Glioblastoma microvesicles transport RNA and proteins that promote tumor growth and provide diagnostic biomarkers. Nat Cell Biol 10:1470-1476

18. Alvarez-Erviti L, Seow Y, Yin HF, Betts C, Lakhal S, Wood MJA (2011) Delivery of siRNA to the mouse brain by systemic injection of targeted exosomes. Nat Biotechnol 29(4):341-345

19. Peters DL, Pretorius PJ (2012) Continuous adaptation through genetic communication-a putative role for cell-free DNA. Expert Opin Biol Ther 12:S127-S132

20. Farina A, Sekizawa A, Sugito Y, Iwasaki M, Jimbo M, Saito H, Okai T (2004) Fetal DNA in maternal plasma as a screening variable for preeclampsia. A preliminary nonparametric analysis of detection rate in low-risk nonsymptomatic patients. Prenatal Diag 24:83-86

21. Macher H, Egea-Guerrero JJ, Revuelto-Rey J, Gordillo-Escobar E, Enamorado-Enamorado J, Boza A, Rodriguez A, Molinero P, Guerrero JM, Dominguez-Roldán JM (2012) Role of early cellfree DNA levels decrease as a predictive marker of fatal outcome after severe traumatic brain injury. Clin Chim Acta 414:12-17

22. Atamaniuk J, Vidotto C, Tschan H, Bachl N, Stuhlmeier KM, Müller MM (2004) Increased concentrations of cell-free plasma DNA after exhaustive exercise. Clin Chem 50:1668-1670

23. Jylhävä J, Kotipelto T, Raitala A, Jylhä M, Hervonen A, Hurme M (2011) Aging is associated with quantitative and qualitative changes in circulating cell-free DNA: the vitality 90 study. Mech Ageing Dev 132:20-26

24. Lo YMD, Chan KCA, Sun H, Chen EZ, Jiang P, Lun FMF, Zheng YW, Leung TY, Lau TK, Cantor CR, Chu RWK (2010) Maternal plasma DNA sequencing reveals the genome-wide genetic and mutational profile of the fetus. Sci Transl Med 2:61ra91. doi:10.1126/scitranslmed.3001720

25. Fan HC, Gu W, Wang J, Blumenfeld YJ, El-Sayed YY, Quake SR (2012) Noninvasive prenatal measurement of the fetal genome. Nature 487(7407):320-324

26. Lo Y, Corbetta N, Chamberlain PF, Rai V, Sargent IL, Redman CW, Wainscoat JS (1997) Presence of fetal DNA in maternal plasma and serum. Lancet 350:485-487

27. Bendich A, Wilczok T, Borenfreund E (1965) Circulating DNA as a possible factor in oncogenesis. Science 148:374-376 
28. García-Olmo DC, Domínguez C, García-Arranz M, Anker P, Stroun M, García-Verdugo JM, García-Olmo D (2010) Cell-free nucleic acids circulating in the plasma of colorectal cancer patients induce the oncogenic transformation of susceptible cultured cells. Cancer Res 70:560-567

29. Garcia-Olmo D, Garcia-Arranz M, Clemente LV, Gahan PB, Stroun M (2015) Method for blocking tumor growth. US 20150071986A1

30. Ermakov AV, Konkova MS, Kostyuk SV, Smirnova TD, Malinovskaya EM, Efremova LV, Veiko NN (2011) An extracellular DNA mediated bystander effect produced from low dose irradiated endothelial cells. Mutat Res Fund Mol Mech 712:1-10

31. Glebova K, Veiko N, Kostyuk S, Izhevskaya V, Baranova A (2015) Oxidized extracellular DNA as a stress signal that may modify response to anticancer therapy. Cancer Lett 356:22-33

32. Kostyuk SV, Ermakov AV, Alekseeva AY, Smirnova TD, Glebova KV, Efremova LV, Baranova A, Veiko NN (2012) Role of extracellular DNA oxidative modification in radiation induced bystander effects in human endotheliocytes. Mutat Res Fund Mol Mech 729:52-60

33. Ronquist GK, Larsson A, Ronquist G, Isaksson A, Hreinsson J, Carlsson L, Stavreus-Evers A (2011) Prostasomal DNA characterization and transfer into human sperm. Mol Reprod Dev 78:467-476

34. Cosetti C, Lugini L, Astrologo L, Saggio I, Fais S, Spadafora C (2014) Soma-to-germline transmission of RNA in mice xenografted with human tumor cells: possible transport by exosomes. PLoS One 9(7):e101629. doi:10.1371/journal.pone.0101629

35. Ronquist G, Nilsson B, Hjerten S (1990) Interaction between prostasomes and spermatozoa from human semen. Arch Androl 24(2):147-157

36. Ronquist KG, Ronquist G, Carlsson L, Larsson A (2009) Human prostasomes contain chromosomal DNA. Prostate 69:737-743

37. Sharma A (2014) Novel transcriptome data analysis implicates circulating microRNAs in epigenetic inheritance in mammals. Gene 538:366-372

38. Kariminejad MH, Khorshidian A (2012) Science of breeding and heredity from ancient Persia to modern Iran. Indian J Hum Genet 18:34

39. Schwartz J (2008) In pursuit of the gene-from Darwin to DNA. Harvard University Press, Massachusetts

40. Adams F (1886) The genuine works of Hippocrates. W. Wood, New York

41. Emery AEH (1968) Heredity, disease, and man. Genetics in medicine. University of California Press, California

42. Rivero ME, Von Tschudi JJ (1855) Peruvian antiquities (trans: Hawks FL). A.S. Barnes \& Company, New York

43. Mayr E (1982) The growth of biological thought: diversity, evolution, and inheritance. Harvard University Press, Massachusetts

44. Darwin E (1809) Zoonomia. Thomas and Andrews, Boston

45. Dercole F, Rinaldi S (2008) Analysis of evolutionary processes. Princeton University Press, New Jersey

46. Koonin EV, Wolf YI (2009) Is evolution Darwinian or/and Lamarckian? Biol Direct 4:42

47. Weismann A, Poulton EB, Schönland S, Shipley AE (1891) Essays upon heredity and kindred biological problems. Clarendon Press, Oxford

48. Weismann A (1893) Germ-plasm: a theory of heredity. Charles Scribner's Sons, New York

49. Sabour D, Schöler HR (2012) Reprogramming and the mammalian germline: the Weismann barrier revisited. Curr Opin Cell Biol 24:716-723

50. Logan CA (2007) Overheated rats, race, and the double gland: Paul Kammerer, Endocrinology and the problem of somatic induction. J Hist Biol 40:683-725
51. Jablonka E, Raz G (2009) Transgenerational epigenetic inheritance: prevalence, mechanisms, and implications for the study of heredity and evolution. Q Rev Biol 84(2):131-176

52. Vanyushin BF (2006) DNA methylation and epigenetics. Russ J Genet 42(9):985-997

53. Naz RK, Sellamuthu R (2006) Receptors in spermatozoa: are they real? J Androl 27(5):627-636

54. Weaver ICG, Vervoni N, Champagne FA, D'Alessio AC, Sharma S, Seckl JR, Dymov S, Szyf M, Meaney M (2004) Epigenetic programming by maternal behavior. Nat Neurosci 7(8):847-854

55. Dias BG, Ressler KJ (2014) Parental olfactory experience influences behavior and neural structure in subsequent generations. Nat Neurosci 17(1):89-96

56. Nelson VR, Heaney JD, Tesar PJ, Davidson NO, Nadeau JH (2012) Transgenerational epigenetic effects of the Apobec1 cytidine deaminase deficiency on testicular germ cell tumor susceptibility and embryonic viability. Proc Natl Acad Sci USA. doi:10.1073/pnas.1207169109

57. Sharma A (2013) Transgenerational epigenetic inheritance: focus on soma to germline information transfer. Prog Biophys Mol Bio 113(2013):439-446

58. Govorko D, Bekdash RA, Zhang C, Sarkar DK (2012) Male germline transmits fetal alcohol adverse effect on hypothalamic proopiomelanocortin gene across generations. Biol Psychiatry $72: 378-388$

59. Pentinat T, Ramon-Krauel M, Cebria J, Diaz R, Jimenez-Chillaron JC (2010) Transgenerational inheritance of glucose intolerance in a mouse model of neonatal overnutrition. Endocrinology 151:5617-5623

60. Zeybel M, Hardy T, Wong YK, Mathers JC, Fox CR, Gackowska A, Oakley F, Burt AD, Wilson CL, Anstee QM, Barter MJ, Masson S, Elsharkawy AM, Mann DA, Mann J (2012) Multigenerational epigenetic adaptation of the hepatic woundhealing response. Nat Med 18:1369-1377

61. Hübner K, Fuhrmann G, Christenson LK, Kehler J, Reinbold R, De La Fuente R, Wood J, Strauss JF, Boiani M, Schöler HR (2003) Derivation of oocytes from mouse embryonic stem cells. Science 300(5623): 1251-1256

62. Takahashi K, Yamanaka S (2006) Induction of pluripotent stem cells from mouse embryonic and adult fibroblast cultures by defined factors. Cell 126:663-676

63. Gahan PB (2013) Circulating nucleic acids: possible inherited effects. Biol J Linn Soc 110:931-948

64. Slavet E (2008) Freud's 'Lamarckism'and the politics of racial science. J Hist Biol 41:37-80

65. Vargas AO (2009) Did Paul Kammerer discover epigenetic inheritance? A modern look at the controversial midwife toad experiments. J Exp Zool 312:667-678

66. Kammerer P (1924) Inheritance of acquired characteristics. Boni and Liveright, New York

67. Gershenowitz H (1983) Arthur Koestlers osculation with Lamarckism and neo-Lamarckism. Indian J Hist Sci 18:1-18

68. Koestler A (1971) The case of the midwife toad. Hutchinson, London

69. Wagner GP (2009) Paul Kammerer's midwife toads: about the reliability of experiments and our ability to make sense of them. J Exp Zool 312:665-666

70. Smuts JC (1927) Holism and evolution, 2nd edn. Greenwood Press, Westport

71. Darwin C (1868) The variation of animals and plants under domestication. John Murray, London

72. Liu Y (2008) A new perspective on Darwin's Pangenesis. Biol Rev 83:141-149

73. Liu Y (2006) Historical and mordern genetics of plant graft hybridization. Adv Genet 56:101-129 
74. Liu Y, Li X (2012) Darwin's Pangenesis and molecular medicine. Trends Mol Med 18:506-508

75. Galton F (1870) Experiments in Pangenesis, by breeding from rabbits of a pure variety, into whose circulation blood taken from other varieties had previously been largely transfused. Proc R Soc London 19:393-410

76. Pearson K (1900) The grammar of science, 2nd edn. Adam and Charles Black, London

77. Liu Y (2011) Inheritance of acquired characters in animals: a historical overview, further evidence and mechanistic explanations. Ital J Zool 78:410-417

78. Hagemann R (2002) How did East German genetics avoid Lysenkoism? Trends Genet 18(6):320-324

79. Li X, Liu Y (2010) Conversion of spring wheat into winter wheat and vice versa: false claim or Lamarckian inheritance? J Biosci 35(2):321-325

80. Medvedev ZA (1969) The rise and fall of TD Lysenko. Columbia University Press, New York

81. Soyfer VN (1994) Lysenko and the tragedy of Soviet science. Rutgers University Press, New Brunswick

82. Graur D, Gouy M, Wool D (2009) In retrospect: Lamarck's treatise at 200. Nature 460:688-689

83. Dahm R (2005) Friedrich Miescher and the discovery of DNA. Dev Biol 278:274-288

84. Soyfer VN (2001) The consequences of political dictatorship for Russian science. Nat Rev Genet 2:723-729

85. Alloway JL (1932) The transformation in vitro of R pneumococci into $\mathrm{S}$ forms of different specific types by the use of filtered pneumococcus extracts. J Exp Med 55:91-99

86. Alloway JL (1933) Further observations on the use of pneumococcus extracts in effecting transformation of type in vitro. J Exp Med 57:265-278

87. Dawson MH (1930) The transformation of pneumococcal types: II. The interconvertibility of type-specific $S$ pneumococci. J Exp Med 51:123-147

88. Dawson MH, Sia RH (1931) In vitro transformation of pneumococcal types: I. A technique for inducing transformation of pneumococcal types in vitro. J Exp Med 54:681-699

89. Berry G, Dedrick HM (1936) A method for changing the virus of rabbit fibroma (Shope) into that of infectious myxomatosis (Sanarelli). J Bacteriol 31:50-51

90. Catlin BW (1960) Transformation of Neisseria meningitidis by deoxyribonucleates from cells and from culture slime. J Bacteriol 79:579-590

91. Catlin BW (1960) Interspecific transformation of Neisseria by culture slime containing deoxyribonucleate. Science 131:608-610

92. Ottolenghi E, Hotchkiss RD (1960) Appearance of genetic transforming activity in pneumococcal cultures. Science 132:1257-1258

93. Borenfreund E, Bendich A (1961) A study of the penetration of mammalian cells by deoxyribonucleic acids. J Biophys Biochem Cytol 9:81-91

94. Vorbrodt A, Wilczok T, Schneiberg K, Gorki T (1963) Autoradiographic studies of the fate of heterologous DNA after injection into mice. Neoplasma 10:355-359

95. Sopikov P (1950) A new method of vegetative hybridization in poultry by blood transfusion. Priroda 39:66

96. Sopikov P (1954) Changes in heredity by the parenteral administration of blood. Agrobiogiia 6:34-45

97. Kushner H (1958) Inheritance of changes in feathering pigmentation in fowls (hens) subjected to foreign blood transfusion. Proc Int Cong Genet 2:155

98. Gromov A (1959) Changes induced in hens by the transfer of foreign blood. Ptitsevodstvo 9(11):26-27
99. Stroun J, Stroun-Guttieres L, Rossi J, Stroun M (1963) Transfer to the progeny of alterations induced in the White Leghorn by repeated injections of heterologous blood. Arch Sci 16:247-262

100. Benoit J, Leroy P, Vendrely R, Vendrely C (1960) Section of biological and medical sciences: experiments on Pekin ducks treated with DNA from Khaki Campbell ducks. Trans N Y Acad Sci 22:494-503

101. Stroun M (2011) Reflections on a life of CNAPS: From circulating DNA to the virtosome. In: Gahan P (ed) Circulating nucleic acids in plasma and serum: proceedings of the 6th international conference on circulating nucleic acids in plasma and serum held on 9-11 November 2009 in Hong Kong. Springer, Netherlands, pp 15-20

102. Stroun M, Mathon C, Stroun J (1963) Modifications transmitted to the offspring, provoked by heterograft in Solanum melongena. Arch Sci 16:225-245

103. Stroun M, Mathon C, Stroun J (1963) Alteration of hereditary traits in Solanum melongena induced by grafts with Solanum nigrum. Proc Int Cong Genet 1:218

104. Gahan PB, Chayen J (1965) Cytoplasmic deoxyribonucleic acid. Int Rev Cytol 18:223-247

105. Stroun M, Anker P, Ledoux L (1966) Fate of bacterial DNA in Solanum lycopersicum esc. Nature 212:397-398

106. Bell E (1969) I-DNA: its packaging into I-somes and its relation to protein synthesis during differentiation. Nature 224:326-328

107. Bell E (1971) Informational DNA synthesis distinguished from that of nuclear DNA by inhibitors of DNA synthesis. Science 174:603-606

108. Anker P, Stroun M (1972) Bacterial ribonucleic acid in the frog brain after a bacterial peritoneal infection. Science 178(4061):621-623

109. Stroun M, Anker P (1973) Transcription of spontaneously released bacterial deoxyribonucleic acid in frog auricles. $\mathrm{J}$ Bacteriol 114:114-120

110. Gahan PB (2003) Messenger DNA in higher plants. Cell Biochem Funct 21:207-209

111. Gahan PB (2006) Circulating DNA. Ann NY Acad Sci 1075:21-33

112. Leon S, Shapiro B, Sklaroff D, Yaros M (1977) Free DNA in the serum of cancer patients and the effect of therapy. Cancer Res 37:646-650

113. Tan E, Schur P, Carr R, Kunkel H (1966) Deoxyribonucleic acid (DNA) and antibodies to DNA in the serum of patients with systemic lupus erythematosus. J Clin Invest 45:1732

114. Ziegler A, Zangemeister-Wittke U, Stahel RA (2002) Circulating DNA: a new diagnostic gold mine? Cancer Treat Rev 28:255-271

115. Garcia-Olmo D, Garcia-Olmo DC, Ontanon J, Martinez E (2000) Horizontal transfer of DNA and the "genometastasis hypothesis". Blood 95:724-725

116. García-Olmo DC, Guadalajara H, Dominguez-Berzosa C, Picazo MG, García-Arranz M, García-Olmo D (2011) Functionality of CNAPS in cancer: The theory of genometastasis. In: Gahan PB (ed) Circulating nucleic acids in plasma and serum: proceedings of the 6th international conference on circulating nucleic acids in plasma and serum held on 9-11 November 2009 in Hong Kong. Springer, Netherlands, pp 105-108

117. Trejo-Becerril C, Pérez-Cárdenas E, Taja-Chayeb L, Anker P, Herrera-Goepfert R, Medina-Velázquez LA, Hidalgo-Miranda A, Pérez-Montiel D, Chávez-Blanco A, Cruz-Velázquez J (2012) Cancer progression mediated by horizontal gene transfer in an in vivo model. PLoS One 7:e52754. doi:10.1371/journal. pone. 0052754

118. Liu Y (2010) Darwin's gemmules and oncogenes. Ann Oncol 21(4):908 
119. Ermakov AV, Konkova MS, Kostyuk SV, Izevskaya VL, Baranova A, Veiko NN (2013) Oxidized extracellular DNA as a stress signal in human cells. Oxidative Med Cell Longev. doi:10. $1155 / 2013 / 649747$

120. Emerit I, Arutyunyan R, Oganesian N, Levy A, Cernjavsky L, Sarkisian T, Pogossian A, Asrian K (1995) Radiation-induced clastogenic factors: anticlastogenic effect of Ginkgo biloba extract. Free Radic Biol Med 18:985-991

121. Mothersill C, Seymour C (2001) Radiation-induced bystander effects: past history and future directions. Radiat Res 155:759-767

122. Seymour CB, Mothersill C (2000) Relative contribution of bystander and targeted cell killing to the low-dose region of the radiation dose-response curve. Radiat Res 153:508-511

123. Ermakov AV, Konkova MS, Kostyuk SV, Egolina NA, Efremova LV, Veiko NN (2009) Oxidative stress as a significant factor for development of an adaptive response in irradiated and nonirradiated human lymphocytes after inducing the bystander effect by low-dose X-radiation. Mutat Res Fund Mol Mech 669:155-161

124. Adams DH, Diaz N, Gahan PB (1997) In vitro stimulation by tumour cell media of $[3 \mathrm{H}]$-thymidine incorporation by mouse spleen lymphocytes. Cell Biochem Funct 15:119-126

125. Bronkhorst AJ, Aucamp J, Wentzel JF, Pretorius PJ (2016) Reference gene selection for in vitro cell-free DNA analysis and gene expression profiling. Clin Biochem. doi:10.1016/j. clinbiochem.2016.01.022

126. Puszyk WM, Crea F, Old RW (2009) Unequal representation of different unique genomic DNA sequences in the cell-free plasma DNA of individual donors. Clin Biochem 42(2009):736-738

127. Ahlstrom L, Euler HV, Hevesy GV (1944) Die wirkung van röntgenstrahlen auf den nukleinsäureumsatz in den organen der ratte. Arkiv för kemi, mineralogi och geologi A 19(9)

128. Hevesy G (1963) Life span of tissue cells. Acta Chem Scand 17(1963):S17-S22

129. Pelc SR (1958) Nuclear uptake of labelled adenine in the seminal vesicle of the mouse. Exp Cell Res 14:301-315

130. Pelc SR (1959) Metabolic activity of DNA as shown by autoradiographs. Lab Invest 8:225-236

131. Pelc SR, Gahan P (1959) Incorporation of labelled thymidine in the seminal vesicle of the mouse. Nature 183:335-336

132. Pelc SR (1962) Incorporation of tritiated thymidine in various organs of the mouse. Nature 193:793-795

133. Ficq A, Pavan C (1957) Autoradiography of polytene chromosomes of Rhynchosciara angelae at different stages of larval development. Nature 180:983-984

134. Pelc SR (1963) On the question of renewal of differentiated cells. Exp Cell Res 29:194-198

135. Bedi K, Goldstein D (1978) Microdensitometric and autoradiographic comparison of the DNA contents of foetal and adult rat liver nuclei. Histochemistry 55:63-74

136. Gall JG, Johnson WW (1960) Is there "metabolic" DNA in the mouse seminal vesicle? J Biophys Biochem Cy 7:657-666

137. Mares V, Schultze B, Maurer W (1974) Stability of DNA in Purkinje cell nuclei of the mouse. An autoradiographic study. J Cell Biol 63:665-674

138. Schultze B (1969) Physical techniques in biological research: autoradiography at the cellular level, 2nd edn. Academic Press, New York

139. Pelc SR (1964) Labelling of DNA and cell division in so called non-dividing tissues. J Cell Biol 22:21-28

140. Lima-de-Faria A, Nilsson B, Cave D, Puga A, Jaworska H (1968) Tritium labelling and cytochemistry of extra DNA in Acheta. Chromosoma 25:1-20

141. Lima-de-Faria A (1962) Metabolic DNA in Tipula oleracea. Chromosoma 13:47-59
142. Lima-de-Faria A, Moses MJ (1966) Ultrastructure and cytochemistry of metabolic DNA in Tipula. J Cell Biol 30:177-192

143. Flickinger CJ (1965) The fine structure of the nuclei of $T e$ trahymena pyriformis throughout the cell cycle. J Cell Biol 27:519-529

144. Gall JG (1959) Macronuclear duplication in the ciliated protozoan euplotes. J Biophys Biochem Cytol 5:295-308

145. Pelc SR (1970) Metabolic DNA and the problem of ageing. Exp Gerontol 5:217-226

146. Sampson M, Davies D (1966) Synthesis of a metabolically labile DNA in the maturing root cells of Vicia faba. Exp Cell Res 43:669-673

147. Sampson M, Katoh A, Hotta Y, Stern H (1963) Metabolically labile deoxyribonucleic acid. Proc Natl Acad Sci USA 50:459-463

148. Sampson M, Clarkson D, Davies DD (1965) DNA synthesis in aluminium-treated roots of barley. Science 148:1476-1477

149. Stroun M, Charles P, Pelc S, Anker P (1967) Metabolic DNA in heart and skeletal muscle and in the intestine of mice. Nature 216:716-717

150. Appleton TC, Pelc SR, Tarbit MH (1969) Formation and loss of DNA in intestinal epithelium. J Cell Sci 5:45-55

151. Pelc SR (1968) Turnover of DNA and function. Nature 219:162-163

152. Hurst PR, Gahan PB, Snellen JW (1973) Turnover of labelled DNA in differentiated collenchyma. Differentiation 1:261-266

153. Hurst PR, Gahan PB (1975) Turnover of DNA in ageing tissues of Lycopersicon escultentum. Ann Bot 29:71-76

154. Giese AC, Suzuki S, Jenkins RA, Hirshfield HI, Isquith IR, DiLorenzo AM (1973) Blepharisma: the biology of a lightsensitive protozoan. Stanford University Press, California

155. Williams NE, Williams RJ (1976) Macronuclear division with and without microtubules in Tetrahymena. J Cell Sci 20:61-77

156. Stroun M, Anker P, Lyautey J, Lederrey C, Maurice PA (1987) Isolation and characterization of DNA from the plasma of cancer patients. Eur J Cancer Clin Oncol 23:707-712

157. Gahan PB, Swaminathan R (2008) Circulating nucleic acids in plasma and serum. Ann NY Acad Sci 1137:1-6

158. Peters DL, Pretorius PJ (2011) Origin, translocation and destination of extracellular occurring DNA-a new paradigm in genetic behaviour. Clin Chim Acta 412:806-811

159. Skvortsova TE, Bryzgunova OE, Lebedeva AO, Mak VV, Vlassov VV, Laktionov PP (2011) Methylated cell-free DNA in vitro and in vivo. In: Gahan $\mathrm{P}$ (ed) Circulating nucleic acids in plasma and serum: proceedings of the 6th international conference on circulating nucleic acids in plasma and serum held on 9-11 November 2009 in Hong Kong. Springer, Netherlands, pp 185-194

160. González-Masiá JA, García-Olmo D, García-Olmo DC (2013) Circulating nucleic acids in plasma and serum (CNAPS): applications in oncology. OncoTarget Ther 6:819-832

161. Koffler D, Agnello V, Winchester R, Kunkel HG (1973) The occurrence of single-stranded DNA in the serum of patients with systemic lupus erythematosus and other diseases. J Clin Invest $52: 198$

162. Saukkonen K, Lakkisto P, Pettila V, Varpula M, Karlsson S, Ruokonen E, Pulkki K, for the Finnsepsis Study Group (2008) Cell-free plasma DNA as a predictor of outcome in severe sepsis and septic shock. Clin Chem 54:1000-1007

163. Velders M, Treff G, Machus K, Bosnyák E, Steinacker J, Schumann U (2014) Exercise is a potent stimulus for enhancing circulating DNase activity. Clin Biochem 47:471-474

164. Jahr S, Hentze H, Englisch S, Hardt D, Fackelmayer FO, Hesch RD, Knippers R (2001) DNA fragments in the blood plasma of cancer patients: quantitations and evidence for their origin from apoptotic and necrotic cells. Cancer Res 61:1659-1665 
165. Spisák S, Solymosi N, Ittzés P, Bodor A, Kondor D, Vattay G, Barták BK, Sipos F, Galamb O, Tulassay Z (2013) Complete genes may pass from food to human blood. PLoS One 8:e69805. doi:10.1371/journal.pone.0069805

166. Mouliere F, Robert B, Peyrotte EA, Rio MD, Ychou M, Molina F, Gongora C, Thierry AR (2011) High fragmentation characterizes tumour-derived circulating DNA. PLoS One 6(9):e23418. doi:10.1371/journal.pone.0023418

167. Bronkhorst AJ, Wentzel JF, Aucamp J, Van Dyk E, Du Plessis L, Pretorius PJ (2016) Characterization of the cell-free DNA released by cultured cancer cells. Biochim Biophys Acta 1863(2016):157-165

168. Barteneva NS, Fasler-Kan E, Bernimoulin M, Stern JN, Ponomarev ED, Duckett L, Vorobjev IA (2013) Circulating microparticles: square the circle. BMC Cell Biol 14:23

169. Distler JH, Pisetsky DS, Huber LC, Kalden JR, Gay S, Distler O (2005) Microparticles as regulators of inflammation: novel players of cellular crosstalk in the rheumatic diseases. Arthritis Rheum 52:3337-3348

170. Flaumenhaft R (2006) Formation and fate of platelet microparticles. Blood Cell Mol Dis 36:182-187

171. Shet AS (2008) Characterizing blood microparticles: technical aspects and challenges. Vasc Health Risk Manag 4(4):769

172. Raposo G, Stoorvogel W (2013) Extracellular vesicles: exosomes, microvesicles, and friends. J Cell Biol 200:373-383

173. Mause SF, Weber C (2010) Microparticles protagonists of a novel communication network for intercellular information exchange. Circ Res 107:1047-1057

174. Deregibus MC, Cantaluppi V, Calogero R, Lo Iacono M, Tetta C, Biancone L, Bruno S, Bussolati B, Camussi G (2007) Endothelial progenitor cell derived microvesicles activate an angiogenic program in endothelial cells by a horizontal transfer of mRNA. Blood 110:2440-2448

175. Heijnen HF, Schiel AE, Fijnheer R, Geuze HJ, Sixma JJ (1999) Activated platelets release two types of membrane vesicles: microvesicles by surface shedding and exosomes derived from exocytosis of multivesicular bodies and alpha-granules. Blood 94:3791-3799

176. Muralidharan-Chari V, Clancy J, Plou C, Romao M, Chavrier P, Raposo G, D'Souza-Schorey C (2009) ARF6-regulated shedding of tumor cell-derived plasma membrane microvesicles. Curr Biol 19:1875-1885

177. Ronquist G, Brody I, Gottfries A, Stegmayr B (1978) An $\mathrm{Mg}^{2+}$ and $\mathrm{Ca}^{2+}$-stimulated adenosine triphosphatase in human prostatic fluid-part II. Andrologia 10:427-433

178. Booth AM, Fang Y, Fallon JK, Yang JM, Hildreth JE, Gould SJ (2006) Exosomes and HIV Gag bud from endosome-like domains of the T cell plasma membrane. J Cell Biol 172:923-935

179. Bronkhorst AJ, Aucamp J, Pretorius PJ (2015) Cell-free DNA: preanalytical variables. Clin Chim Acta 450(2015):243-253

180. Bennett RM, Gabor GT, Merritt MM (1985) DNA binding to human leukocytes. Evidence for a receptor-mediated association, internalization, and degradation of DNA. J Clin Invest 76:2182-2190

181. Breitbach S, Tug S, Simon P (2012) Circulating cell-free DNA: an up-coming molecular marker in exercise physiology. Sports Med 42:565-586

182. Mittra I, Nair NK, Mishra PK (2012) Nucleic acids in circulation: are they harmful to the host? J Biosci 37:301-312

183. Holdenrieder S, Stieber P (2009) Clinical use of circulating nucleosomes. Crit Rev Clin Lab Sci 46:1-24

184. Théry C (2011) Exosomes: secreted vesicles and intercellular communications. F1000 Biol Rep 3:15

185. Taylor SW, Fahy E, Ghosh SS (2003) Global organellar proteomics. Trends Biotechnol 21:82-88
186. Valadi H, Ekström K, Bossios A, Sjöstrand M, Lee JJ, Lötvall JO (2007) Exosome-mediated transfer of mRNAs and microRNAs is a novel mechanism of genetic exchange between cells. Nat Cell Biol 9:654-659

187. García-Olmo D, Garcia-Olmo D, Ontanon J, Martinez E, Vallejo M (1999) Tumor DNA circulating in the plasma might play a role in metastasis. The hypothesis of the genometastasis. Histol Histopathol 14:1159-1164

188. Waldenström A, Gennebäck N, Hellman U, Ronquist G (2012) Cardiomyocyte microvesicles contain DNA/RNA and convey biological messages to target cells. PLoS One 7:e34653. doi:10. 1371/journal.pone.0034653

189. Kahlert C, Melo SA, Protopopov A, Tang J, Seth S, Koch M, Zhang J, Weitz J, Chin L, Futreal A, Kalluri R (2014) Identification of double-stranded genomic DNA spanning all chromosomes with mutated KRAS and p53 DNA in the serum exosomes of patients with pancreatic cancer. J Biol Chem 289:3869-3875

190. Thakur BK, Zhang H, Becker A, Matei I, Huang Y, Costa-Silva B, Zheng Y, Hoshino A, Brazier H, Xiang J (2014) Doublestranded DNA in exosomes: a novel biomarker in cancer detection. Cell Res 24:766-769

191. Chen W, Liu X, Lv M, Chen L, Zhao J, Zhong S, Ji M, Hu Q, Luo Z, Wu J, Tang J (2014) Exosomes from drug-resistant breast cancer cells transmit chemoresistance by a horizontal transfer of microRNAs. PLoS One 9:e95240. doi:10.1371/ journal.pone.0095240

192. Sousa D, Lima RT, Vasconcelos MH (2015) Intercellular transfer of cancer drug resistance traits by extracellular vesicles. Trends Mol Med 21(10):595-608

193. Ronquist G, Brody I (1985) The prostasome: its secretion and function in man. Biochim Biophys Acta 822:203-218

194. Johnstone RM, Adam M, Hammond JR, Orr L, Turbide C (1987) Vesicle formation during reticulocyte maturation. association of plasma membrane activities with released vesicles (exosomes). J Biol Chem 262:9412-9420

195. Ronquist G (2011) Prostasomes are mediators of intercellular communication: from basic research to clinical implications. J Intern Med 271:400-413

196. Hessvik NP, Phuyal S, Brech A, Sandvig K, Llorente A (2012) Profiling of microRNAs in exosomes released from PC-3 prostate cancer cells. BBA Gene Regul Mech 1819:1154-1163

197. Carballada R, Esponda P (2001) Regulation of foreign DNA uptake by mouse spermatozoa. Exp Cell Res 262:104-113

198. Eaton SA, Jayasooriah N, Buckland ME, Martin DIK, Cropley JE, Suter CM (2015) Roll over Weismann: extracellular vesicles in the transgenerational transmission of environmental effects. Epigenomics 7(7):1165-1171

199. Vickers KC, Palmisano BT, Shoucri BM, Shamburek RD, Remaley AT (2011) MicroRNAs are transported in plasma and delivered to recipient cells by high-density lipoproteins. Nat Cell Biol 13:423-433

200. Arroyo JD, Chevillet JR, Kroh EM, Ruf IK, Pritchard CC, Gibson DF, Mitchell PS, Bennett CF, Pogosova-Agadjanyan EL, Stirewalt DL (2011) Argonaute2 complexes carry a population of circulating microRNAs independent of vesicles in human plasma. Proc Natl Acad Sci USA 108:5003-5008

201. Ho MW (2010) Development and evolution revisited. In: Hood KE, Halpern CT, Greenberg G, Lerner RM (eds) Handbook of developmental science, behavior, and genetics. Blackwell Publishing Ltd, West Sussex, pp 61-109

202. Jablonka E, Lamb MJ, Avital E (1998) 'Lamarckian'mechanisms in Darwinian evolution. Trends Ecol Evol 13:206-210

203. Shapiro JA (2013) How life changes itself: the Read-Write (RW) genome. Phys Life Rev 10:287-323 
204. Astolfi PA, Salamini F, Sgaramella V (2010) Are we genome mosaics? Variations of the genome of somatic cells can contribute to diversify our phenotypes. Curr Genomics 11:379-386

205. Biedler JL, Spengler BA (1976) Metaphase chromosome anomaly: association with drug resistance and cell-specific products. Science 191:185-187

206. Sager R, Gadi IK, Stephens L, Grabowy CT (1985) Gene amplification: an example of accelerated evolution in tumorigenic cells. Proc Natl Acad Sci USA 82:7015-7019

207. Schimke RT, Beverly S, Brown P, Cassin R, Federspiel N, Gasser C, Hill A, Johnston R, Mariani B, Mosse E, Rath H, Smouse D, Tisty T (1984) Gene amplification and drug resistance in cultured animal cells. Cancer Treat Rev 2:9-17

208. Aldana M, Balleza E, Kauffman S, Resendiz O (2007) Robustness and evolvability in genetic regulatory networks. J Theor Biol 245(2007):433-448

209. Wilmut I, Campbell K, Tudge C (2000) The second creation: dolly and the age of biological control. Farrar, Strauss and Giroux, USA

210. Pearson H (2006) Human genome completed (again). Nature News. http://www.nature.com/news/2006/060515/full/news060515-12. html. Accessed 24 Nov 2014

211. Przibram H (1912) Die umwelt des keimplasmas. I. Das arbeitsprogramm. Archiv für Entwicklungsmechanik der Organismen 33(3):666-681
212. Blackburn GM, Gait MJ, Loakes D, Williams DM (2006) Nucleic acids in chemistry and biology, 3rd edn. The Royal Society of Chemistry, Cambridge

213. Wanscher JH (1975) An analysis of Wilhelm Johannsen's genetical term "genotype" 1909-26. Hereditas 79:1-4

214. Lee HO, Davidson JM, Duronio RJ (2009) Endoreplication: polyploidy with purpose. Gene Dev 23:2461-2477

215. Benyajati C, Worcel A (1976) Isolation, characterization, and structure of the folded interphase genome of Drosophila melanogaster. Cell 9:393-407

216. Sorsa V (1986) Distribution of chromomeres as a basis of chromosomal coiling. J Cell Sci 80:193-205

217. Andersson K, Björkroth B, Daneholt B (1984) Packing of a specific gene into higher order structures following repression of RNA synthesis. J Cell Biol 98:1296-1303

218. Matzke MA, Birchler JA (2005) RNAi-mediated pathways in the nucleus. Nat Rev Genet 6:24-35

219. Mpoke S, Wolfe J (1996) DNA digestion and chromatin condensation during nuclear death in Tetrahymena. Exp Cell Res $225: 357-365$ 